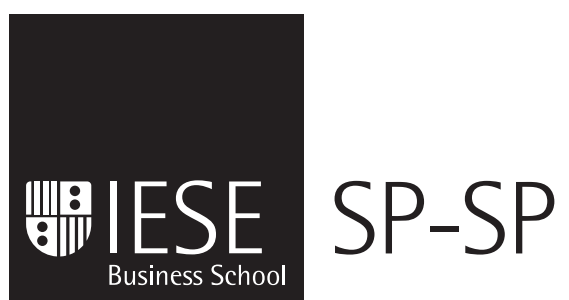

Working Paper

WP no 665

January, 2007

University of Navarra

\title{
REGULATORY REFORM, DEVELOPMENT AND DISTRIBUTIVE CONCERNS
}

\author{
Francesc Trillas \\ Gianandrea Staffiero
}


The Public-Private Center is a Research Center based at IESE Business School. Its mission is to develop research that analyses the relationships between the private and public sectors primarily in the following areas: regulation and competition, innovation, regional economy and industrial politics and health economics.

Research results are disseminated through publications, conferences and colloquia. These activities are aimed at fostering cooperation between the private sector and public administrations, as well as the exchange of ideas and initiatives.

The sponsors of the SP-SP Center are the following:

- Accenture

- Ajuntament de Barcelona

- Official Chamber of Commerce, Industry and Navigation of Barcelona

- BBVA

- Diputació de Barcelona

- Garrigues, Abogados y Asesores Tributarios

- Catalan Government (Generalitat de Catalunya)

- Sanofi-Aventis

- Telefonica

- T-Systems

- VidaCaixa

The contents of this publication reflect the conclusions and findings of the individual authors, and not the opinions of the Center's sponsors. 


\title{
REGULATORY REFORM, DEVELOPMENT AND DISTRIBUTIVE CONCERNS
}

\author{
Francesc Trillas * \\ Gianandrea Staffiero**
}

\begin{abstract}
This survey reviews the relationship between regulation and distribution, focusing on regulatory reform in developing countries. The characteristics of these countries impose constraints on appropriate regulatory policies. These constraints condition i) the terms of the tradeoff between firms' rents and efficiency, including the commitment problem in the presence of sunk investments, and ii) the probability of success in removing cross subsidies. The choices made when reforming infrastructure industries may have a significant impact on perceived distribution and development, and this impact will drive attitudes towards reform. Distributive problems are channeled through politics and institutions, conditioning the potential solutions to the commitment problem. These issues have been extensively explored by the academic literature, and provide guidance on how to address second generation regulatory reforms.
\end{abstract}

\footnotetext{
* Universitat Autònoma de Barcelona

** Post-Doctoral Research Fellow, IESE
}

Clasificación JEL: L5, 012.

Keywords: Regulation, privatization, infrastructures, development, distribution. 


\section{REGULATORY REFORM, DEVELOPMENT AND DISTRIBUTIVE CONCERNS}

\section{Introduction}

The existence of a relationship between regulation and distribution is sometimes simply denied, since the dominant objective of regulation, as typically stated both in economic models and in economic policy circles, is efficiency. ${ }^{1}$ However, a closer look at the evidence and at recent academic work leads the observer to think that policy makers, investors and regulatory economists would ignore distributive concerns at their peril.

Evidence from Latin America is especially interesting, since in the 1990s the region was a laboratory for regulatory reform. By regulatory reform, we mean the institutional and structural changes that took place in infrastructure industries ${ }^{2}$ in the 1990s, including liberalization and privatization. Kessides (2004, p.11) shows that private investment in infrastructures in developing and transition countries peaked at around $\$ 130$ billion in 1997, but by 2001 had fallen to about $\$ 60$ billion. ${ }^{3}$ Privatization activity in developing countries has been unevenly distributed, with Latin America accounting for most of the privatizations. Foreign investment played an important role. Parker and Kirkpatrick (2005, p. 514) report that foreign participation in developing countries following privatization reached $76 \%$ of total proceeds in 1999, of which foreign direct investment accounted for $80 \%$.

In this paper we review the theoretical and empirical evidence relating regulatory reform to development and distribution. We also analyze to what extent some microeconomic policies, originally designed in the context of economically advanced countries, require changes when applied to developing countries. Furthermore, we seek clues in the academic literature to guide

\footnotetext{
1 Analogously, linking macroeconomics and distribution is seen in some contexts as an oxymoron, since macroeconomics is mainly concerned with aggregate phenomena. Bertola (2000) and Bertola et al. (2006) provide convincing arguments precisely in the opposite direction.

${ }^{2}$ By infrastructure industries we mean those industries that require heavy, highly specific investments in fixed costs, usually in the form of physical networks, such as telecommunications, energy, transport, water and sanitation. Infrastructure industries, public utilities and network industries are concepts that are often used as synonyms in the literature. International institutions and especially the World Bank usually employ the term "infrastructure industries."

${ }^{3}$ See also Harris (2003).
} 
what some have called "second generation" reforms ${ }^{4}$ aimed at providing stability and permanence to foreign private investment in the infrastructure sectors in developing countries, most notably in Latin America. Kessides (2004, p. 52), in a study commissioned by the World Bank, reports survey data from the "Latinobarómetro" about the public's sentiment vis-à-vis privatization. Comparing answers in 1998, 2000 and 2002 the percentage of the population who disapproved of privatization policies had increased in Argentina, Bolivia, Brazil, Chile, Mexico, Nicaragua and Peru. Whereas in most of these countries the figure was around 40\% in 1998, it had increased to well above 60\% in all those countries in 2002. In 2002 nearly 90\% of Argentineans and 80\% of Chileans polled disapproved of privatization, "despite demonstrable improvements in the performance of privatized firms."

This "disillusionment" 5 has been driven, according to Kessides, by "employee layoffs, price increases, perceived long delays in benefits, and the distributional impacts of privatization." Recent political unrest in some Latin American countries (such as Argentina and Bolivia) has focused, inter alia, on the role of foreign private investment.

Although historically the emphasis of regulatory economics has been on efficiency, the attention paid to distributional concerns is not new. Distributive issues are actually at the core of some regulatory dilemmas, such as the tradeoff between rent and efficiency (by which to achieve efficient results, such as high investment, some positive rent levels must be guaranteed to regulated firms), and the tension between liberalization and cross subsidies (by which prices are above cost in some regulated segments to fund the deficits in high cost or politically sensitive segments).

If dilemmas relating to firms' rents and efficiency exist in democratic societies with high inequality, the existence of political problems when these rents are made more transparent (for example, through well audited foreign multinationals) should not be surprising. At least since the 1960s, inequality in Latin American countries has been higher than in any other region of the world.

In this paper we review the literature on these issues, and argue that regulatory reforms ${ }^{6}$ should be devised taking into account the specific features of developing countries, including income inequality. We report that regulatory reforms have been perceived to have an unbalanced impact on different population segments, and that institutions are a key ingredient to understanding the link between regulatory reform and development. There are other studies that survey regulation and development; see for example Cook et al. (2004). But ours is the first that focuses simultaneously on the tradeoff between rent and efficiency, and on the relationship between institutional issues and this tradeoff.

\footnotetext{
${ }^{4}$ See for example Krueger (2000), Basanes and Willig (2001) and Kessides (2004).

5 Gómez-Ibáñez (2003, p. 342) argues that “continuing frustration over economic reforms associated with privatization, or continuing disputes among consumers, investors, and governments about the fairness of regulated prices, may eventually reduce popular support for private infrastructure to the breaking point." He adds that "the perception of fairness is as important as the reality, so that regulation is as much a political as a technical act."

${ }^{6}$ Estache et al. (2005) identify three main drivers behind the regulatory reform process. The first one, a favorable ideology to market oriented reforms, was spurred by previous experiences in the UK and Chile. Technological changes also brought about new perspectives for the emergence of competition in segments of industries which were traditionally regarded as "natural monopolies" in their entirety. Finally, the fiscal crisis which mainly affected developing countries in the 1980s and mid-1990s reduced the sustainability of financial coverage of largely inefficient public enterprises.
}

2 - IESE Business School-University of Navarra 
Our focus is on infrastructure industries, including (but not limiting ourselves to) telecommunications, in Latin America, although some lessons may be relevant for other regions as well. We focus on democracies, reflecting the trend towards democratization in developing countries in the recent past. Indeed, the increasing role of democracy in Latin American countries has been one of the common features of the region in the late twentieth and early twenty-first centuries, in contrast to a not-so-distant past plagued by military dictatorships.

The rest of this survey is organized as follows: In Section 2 we address the issue of how distributive concerns and the specific features of developing countries condition regulation and other policies related to the infrastructure sector. In Section 3 we analyze the actual impact of regulatory reform packages on development and distribution, both from a microeconomic and a macroeconomic point of view. Section 4 tackles a number of institutional issues, following the view that the main obstacles to reform are political and institutional. In particular, we focus on the regulatory independence debate, on governance issues, and on regulatory capture. Although the sections are topic oriented, Section 2 is more (although not exclusively) focused on theory and Section 3 on empirical studies, whereas Section 4 is more balanced in terms of contents. Finally, Section 5 concludes and suggests areas of future research.

\section{Distribution and Reform Constraints in Developing Countries}

In this section, we explore how efficiency and distributive concerns are related in theory, and why this relationship is an important ingredient of the constraints that regulatory reform faces in developing countries.

A typical regulatory relationship can be summarized with the following simple model (see Evans et al., 2006): A regulated firm chooses investment in Period 1 to maximize the expected discounted sum of two periods' profits, where in Period 2 the regulator fixes a price for the service provided by the firm. Let $i$ be the investment level chosen by the firm; then the firm's objective function is:

$$
\Theta=-i+\delta[(p-c) D(p)-k+f(i)]
$$

where $\delta$ is the discount factor, $\rho$ is the price decided by the regulator in Period 2, $c$ is the marginal cost, and $k$ is the fixed cost. Investment in Period 1 leads to a lowering of fixed costs $f(i)$ in Period 2, with the assumptions $f^{\prime}>0, f^{\prime \prime}<0$ and $f^{\prime}(0)=\infty$. If the regulator only cares about consumer surplus, then it chooses $p$ to maximize consumers' net surplus $S(p)$, subject to the firm's second period break-even constraint, $(p-c) D(p)-k+f(i) \geq 0$. The standard result is that the constraint binds, so there is no incentive to invest, and it must therefore be compared to the first-best investment level. This is achieved by maximizing $-i+\delta f(i)$, so the first-best investment level is given by $\delta f^{\prime}(i *)=1$. This can be achieved by committing, in the first period, to a price that makes first-best investment worthwhile, that is, second period profits must be positive so as to remunerate such an investment. But the ability to commit depends on endogenous country characteristics that will be examined in the rest of this survey. 
In the benchmark theorems about the social desirability of market economies (the two welfare theorems and the Coase theorem), the attainment of efficiency and the attainment of distributive objectives are separable problems. In the case of the Coase theorem, ${ }^{7}$ for example, in the absence of wealth effects and transaction costs, if property rights are well specified, decentralized solutions obtained through bargaining are efficient. The concept of an efficient solution is compatible with different initial allocations of property rights. However, different allocations of property rights give rise to different distributions as part of efficient solutions (of course, if wealth effects are significant, these different distributions are an obstacle to the attainment of efficiency). Milgrom and Roberts (1990), in the context of the economics of organization, point out that a particular sort of transaction cost, namely bargaining costs, usually prevent efficiency and distribution from being separable. To the extent that efficiency is compatible with a number of different distributive solutions, agents will bargain to achieve the one that is closest to their interests. This sort of bargaining introduces costs, and these costs may outweigh potential efficiency gains.

In regulated sectors, if efficiency and distribution were separable, there would be no problem with gearing regulatory decisions towards efficiency and leaving other areas of government to care about distribution. However, some characteristics of regulated sectors, and the particular attributes of these sectors in developing countries, which we review in the rest of this section, make these two concerns far from separable.

The notion that regulation has to be perceived as "fair" to be sustainable has been acknowledged both in developing and in developed countries (see Zajac, 1995). Hence for example the requirement in the US for a "fair rate of return" on assets invested in a regulatory project, which goes beyond the requirement of efficiency. The tension between efficiency and distribution has surfaced in competition or antitrust policy as well, where some have advocated the use, as a policy objective, of consumer surplus maximization as opposed to social welfare maximization, based on the informational (Besanko and Spulber, 1993) and political (Neven and Röller, 2005) weakness of consumers in the face of producers' interests. The orthodox response to this (see Motta, 2004, ch. 1) has been that, i) by definition, efficiency has to take into account the interests of all agents in society, including producers, stressing also that, in many developed countries, consumers also share producers' interests through shared ownership, pension funds and other forms of investment; and ii) in practice, a concern for the long run welfare of consumers will seldom be in contradiction to the welfare of the members of society as a whole. Then, if distribution is a concern, there are other, better instruments with which it can be achieved.

An insightful counter-argument used by those who are against the application of distributive concerns to regulation and competition or antitrust policy is that local justice (the justice related to a particular market or a particular arena - see Elster, 1992) is not necessarily correlated with global justice (justice in society at large). For example high prices for consumers with more inelastic demand may hurt poorer or richer consumers depending on the particular product or geographical market. ${ }^{8}$ The validity of this argument is an empirical question that will be addressed in Section 3 below.

\footnotetext{
${ }^{7}$ See Coase (1960).

${ }^{8}$ See Rey et al. (2005). 
Although historically the emphasis of regulatory economics has been on efficiency, the attention paid to distributional concerns is not new. Distributive issues are actually at the core of some regulatory dilemmas:

- There is a tradeoff between rent and efficiency. In many settings, if the regulator wants to achieve efficient allocations, it must give up costly rents to the firms. The traditional Loeb and Magat scheme ${ }^{9}$ is the easiest way to see this. In a simple setting with linear demand $D(p)$ and keeping the assumption of constant marginal costs (and ignoring investment), if the regulator can transfer subsidies to the firm, but wants to leave price discretion to the operator, and if the subsidy is made equal to the area between demand and marginal cost, the firm will price at marginal cost to maximize producer surplus. In this case producer surplus equals total surplus and first-best efficiency is achieved, but at the cost of extreme inequality, since consumers are left with zero surplus. A regulator could safely do this if it valued producer and consumers rents equally or if raising money for transfers through taxation did not have a social cost in terms of distortions in other (competitive) markets. More generally, in models with asymmetric information, providing incentives to the firm to make costly efforts or sunk investments, or to reveal the true information about costs entails giving up costly rents as part of second-best solutions. ${ }^{10}$

- Cross subsidies ${ }^{11}$ have historically been and still are in many countries a way to overcome the dilemma between allocative efficiency and distortionary taxation. Marginal cost pricing for a natural monopoly involves a deficit for the firm that has to be covered through distortionary taxation, whereas uniform average cost pricing leaves some consumers (usually the poorest) unserved. Then fixing a price above average cost for those more willing to pay, and a price below average costs for those less willing to pay, allows the regulator to achieve an allocation whereby the quantities sold maximize total surplus, and which at the same time is both financially feasible and politically appealing from a distributional point of view. However, if at some point liberalization is contemplated as a desirable option, the entry of new firms will start with the segments of those willing to pay more (for example urban and business segments) and hence entry will undermine cross subsidization. ${ }^{12}$

- In the absence of information asymmetries, the task of the regulator would be simple if there were no commitment or capture problems. There is actually a thin line between avoiding both capture and commitment problems. In fact, in the absence of commitment, some degree of capture may be "used" to give up those costly rents that are necessary to provide incentives for efficiency-oriented innovation. For example, the regulator may not want to know about the firm's costs if that unleashes the ratchet

\footnotetext{
9 See Loeb and Magat (1979).

${ }^{10}$ See Armstrong and Sappington (2003).

${ }^{11}$ See Beato (2002).

${ }^{12}$ Entry would also undermine Ramsey-Boiteux prices, i.e. the structure of prices that optimally satisfies the firm's breakeven constraint, whereby the higher prices are prices above marginal costs the more inelastic the demand. Ramsey prices are actually another instance of the tension between efficiency and distributional politics, since inelastic demand is often disproportionately concentrated in the poorest segments of the population. However, these political reasons, as well as heavy information requirements, are usually blamed for the scarce use of Ramsey tariffs in practice.
} 
effect, ${ }^{13}$ or it may be desirable that consumer/voters do not have a high degree of information on regulatory policies because that would reduce the clout of firms as lobbies and would not secure the rents they need to make investments worthwhile in the absence of commitment (see more on commitment and capture in Section 4).

In relation to this, recent studies on regulation and privatization of infrastructure industries in developing countries start by mentioning a number of characteristics of developing countries, many of them linked to distributive issues, which should be taken into account when designing microeconomic policies. ${ }^{14}$ Laffont (2005) mentions the following characteristics:

- Higher deadweight costs of public funds due to distortionary taxation. The underdevelopment of tax systems implies that collecting one dollar is significantly more costly in developing than in developed economies. World Bank estimates report a deadweight loss exceeding 1 for each unit of funds to be raised against a 0.3 in developed countries. A high cost of the tax system, coupled with enormous social needs and high inequality, entails high pressure to redistribute any rents known to be generated. In particular, there is a high short term opportunity cost of complying with the commitment not to expropriate the quasi-rents necessary to remunerate the sunk investments in infrastructure sectors.

- Higher costs of auditing and enforcement. The inefficiency of the public sector and absence of a well trained bureaucracy form the basis of the problems of underdeveloped institutions in enforcing private contracts.

- Private ordering instead of the rule of law. The behavior of public servants is often shortsighted and dominated by private concerns, translating into relatively low standards of probity in public administration in a number of countries, going so far as cronyism and corruption.

- Lesser ability to enter into long term contracts. Institutions charged with protecting property rights are usually informal, and arenas where agents can engage in credible long term commitments are relatively unusual in less developed countries (LDCs). Poorly protected private property rights and under-developed business codes of behavior are the norm in many of these countries.

The list of special features of developing countries that affect privatization processes should be supplemented, according to Parker and Kirkpatrick (2005), with the following features:

- Imperfectly competitive and incomplete markets. Existing producers often have high market power and there is an absence or scarcity of markets (typically, financial markets) where agents with different allocations across states of nature and over time can exchange their endowments.

\footnotetext{
13 The ratchet effect is the unwillingness to reveal its type or to make an effort by an agent, when he or she anticipates that the positive results of this action will be "expropriated" by some other agent (the "principal") in the future. See Laffont and Tirole (1993).

${ }^{14}$ See also Soria (2005).

6 - IESE Business School-University of Navarra
} 
- Regionalized and sometimes ethnically distinct labor markets, with appointments through connections. Labor markets are thin, and the absence of meritocratic appointments reduces the incentives to invest in human capital. This translates into management weaknesses and patronage in appointments at firms and regulatory institutions.

The combination of Laffont's and Parker and Kirkpatrick's features gives an idea of the complications that arise in regulatory reform policies in developing countries, and in Latin America in particular.

Laffont further explores how industry and market structures, ${ }^{15}$ power of incentives, ${ }^{16}$ access prices and universal service should differ in the light of such specific characteristics. Although we refer the reader to Laffont (2005) for further details, the general conclusion is that policies that would be efficient in developed countries (such as price caps or other "incentive regulation" mechanisms) are much more difficult to sustain in developing countries.

The study presented in Estache, Perelman and Trujillo (2005), based on 1,000 contracts in Latin America, shows that there was a tendency in favor of price caps (used to regulate $56 \%$ of the contracts) vis-à-vis rate or return regulation (20\% of the cases). However, the same authors point out that the "initial enthusiasm for the inclusion of efficiency in the design of regulation in developing countries is, however, being adjusted in developments observed over the last 2-3 years." In that respect, they observe a tendency away from "pure" price or revenue cap regimes in favor of "hybrid" regimes which entail some pass-through of costs to consumers, most notably in activities subject to exchange risks and those involving negotiated long-term arrangements (e.g. labor contracts). The other tendency they observe is the increasing interest in national and international performance benchmarking (yardstick competition) in LDCs, albeit with slow progress. Also, the slowdown in the volumes of private capital in financing infrastructures in LDCs since the 1997 East Asia crisis leads the authors to conclude that "the next generation of contracts seems to be moving towards management contracts" and that "the public sector will continue to be an important actor."

The issue of contract renegotiation with a focus upon LDCs, and in particular the Latin American and Caribbean countries, is studied by Guasch et al. (2002), who combine gametheory analysis and empirical evidence. In a context where concessions and privatizations, rather than management contracts, were the "salient modes of private sector participation," contractual incompleteness and imperfect enforcement leads to a wide scope for renegotiation of contracts. The inherently higher risk entailed by price capping schemes tends to exacerbate the tendency towards renegotiation. The authors find that the existence of an independent regulator ${ }^{17}$ significantly reduces the probability of renegotiations and increases the quality of enforcement by better commitment.

\footnotetext{
${ }^{15}$ Focusing on the electricity industry, Holburn and Spiller (2002) argue that it is a myth that economies of scale in generation limit the potential for competition in small markets. However, Jamasb (2006) argues that electricity retail competition should remain a long term objective in most developing countries, due to implementation costs. On how some small developing countries are able to develop competitive market structures in telecommunications, see Spiller and Cardilli (1997).

${ }^{16}$ Guasch (2004) shows that price caps are a positive determinant of contract renegotiation (the same result is reported in Laffont, 2005).

${ }^{17}$ See Section 4.
} 
The issues relating to Universal Service Obligation (USO) are particularly prominent in the LDC context, especially when urban areas with low costs of access provision are open to competition and cross-subsidization becomes unfeasible. Universal service is often seen as one important aspect of economic development per se, most notably as the expansion of the network has not reached rural areas in many parts of LDCs. The aforementioned high cost of public funds, and therefore the high deadweight loss caused by redistribution through taxation, implies that USO policies are often seen as a sensible instrument for the redistribution of income.

Laffont (2005) develops an insightful theoretical model, based on asymmetric information, of USO policies, and shows that uniform pricing policies distort incentives and therefore exacerbate the problem of the limited expansion of the network in rural areas. He points out that when competition is introduced in low-cost areas, new methods of financing access in high-cost areas must be put in place, for instance via taxation of the industry or on a broader basis. ${ }^{18}$

One conclusion which can be widely agreed upon as emerging from the literature is that policymakers do need to take distribution concerns seriously into account when designing effective universal service policies. Universal service programs ${ }^{19}$ should create special funds (from all operators that achieve a given market share, or from general taxation if the tax system is welldeveloped enough), using the vertical chain of government to carefully target subsidies. It also appears that direct subsidies are usually preferable to cross subsidies because they do not jeopardize liberalization, but they must run in parallel with fiscal policy reform and with an improvement in the quality of government. Otherwise, we would be back to the previous stage, where company deficits were financed through opaque fiscal deficits.

We thus observe that optimal regulatory policies in developing countries face a number of additional constraints. Most of these additional constraints exacerbate the trade-off between rents and efficiency, and hence add distributive demands to optimal policies, generally making reform more difficult to implement or sustain. Policies need to take distribution concerns seriously into account, designing effective universal service policies.

\section{The Effects of Reforms}

\subsection{The Impact of Reform Packages on Distribution}

In this sub-section we explore inequality measures and survey studies that analyze the impact of particular reform packages on inequality and income groups.

At least since the 1960s, inequality in Latin American countries has been higher than in any other region of the world (see de Ferranti et al., 2003). With the exception of countries in SubSaharan Africa, the difference in Gini coefficients between Latin America and other regions is large. This gap narrowed in the 1970s and became wider again in the 1980s. There was no clear pattern in the 1990s, when Latin America performed better than some regions in distributional terms (for example Eastern Europe) and worse than others (for example, South Asia). It is sometimes argued that inequality is related to the state of development in a country and

\footnotetext{
${ }^{18}$ For references to specific universal service schemes targeted at the poor, see Estache et al. (2002).

${ }^{19}$ Chisari et al. (2003) describe and evaluate the different universal service policies existing in Latin America.
} 
comparisons should therefore be made that control for this factor. Even controlling for this factor, however, the authors who present this evidence conclude that the Latin American region suffers from high "excess inequality."

\section{Table 1}

Gini Coefficients by Region

\begin{tabular}{|l|c|c|c|c|}
\hline Region & 1970s & 1980s & 1990s & $\begin{array}{c}\text { Overall } \\
\text { Average }\end{array}$ \\
\hline $\begin{array}{l}\text { Latin America } \\
\text { and Caribbean }\end{array}$ & 48.4 & 50.8 & 52.2 & 50.5 \\
\hline Asia & 40.2 & 40.4 & 41.2 & 40.6 \\
\hline OECD & 32.3 & 32.5 & 34.2 & 33.0 \\
\hline
\end{tabular}

Source: de Ferranti et al. (2003)

In 2003, the richest tenth of the population of Latin America and the Caribbean earned $48 \%$ of total income, while the poorest tenth earned only $1.6 \%$. In industrialized countries, by contrast, the top tenth received 29.1\%, while the bottom tenth earned $2.5 \%$.

Inequality would not be a problem for the private sector investment in infrastructure services if markets and institutions worked perfectly. ${ }^{20}$ Financial markets would allow the implementation of any positive net present value project and private contracts or contracts between the public sector and the private sector would be enforced by well functioning institutions. If inequality has any impact on investment, it must be because some markets and/or institutions do not work perfectly. We contend that more attention should be paid to the fact that inequality triggers political dissatisfaction (because some markets do not distribute resources to the satisfaction of policies, and some policies do not reach the poor sufficiently or have an impact on some sectors such as middle and lower classes which is perceived to be negative), which in turn makes commitment to reward investment difficult. With that perspective in mind, in this section we focus on distributive issues, in particular on what the impact of regulatory reform on consumers has been and to see to what extent this impact may be a source of dissatisfaction.

Harris (2003) and Estache et al. (2002) agree that private investment in infrastructure has been a key factor, in some cases, in expanding the number of connected households. They also agree, however, that since tariffs were usually below average costs in the past, whenever private sector involvement has been accompanied by hardening budget constraints for governments (which has not always been the case according to Engel et al., 2003) tariff rebalancing (the unwinding of cross subsidies) has posed a big political problem. McKenzie and Mookherjee (2003) provide an overview of the distributive impact of the privatization of utilities on four Latin American countries (Argentina, Bolivia, Mexico and Nicaragua). They observe no common pattern

\footnotetext{
${ }^{20}$ See Banerjee (2004).
} 
concerning price changes associated with privatizations, but the price effects were almost always outweighed in welfare terms by gains in service access among the poor, although they admit that the empirical studies are severely constrained by the partial nature of the available data.

Consumer welfare measurement provides a methodology to evaluate the differential impact of regulatory reform across consumer groups. The surplus for a fixed number of consumers is often approximated in empirical studies as the price difference multiplied by a quantity which can be the initial one, the final one or the average. In the case of zero elasticity it suffices to consider the initial quantity. This is the procedure used in Ugaz and Waddams-Price (2003); they measure consumer surplus for several income groups to quantify the impact on welfare of privatizations and associated regulatory reforms for several groups of consumers. This can be used to assess the impact of these policies on inequality and poverty using expenditure surveys, although the methodology suffers from the same problems of any study that analyzes the evolution of variables before and after a change in policy: it is difficult to establish causality links, given that other potential factors are not accounted for, although a (not always credible) counterfactual is usually established. This is a typical problem of privatization studies, according to Parker and Kirkpatrick (2005, p. 515). In spite of this, such studies contribute a great deal of information towards understanding the different reactions vis-à-vis privatization and regulatory reform.

One of the empirical applications that uses consumer surpluses consists of estimating the welfare derived from new products (see Hausman, 1998) or the welfare gains for new consumers. This is what Delfino and Casarin (2003) do for the case of the Buenos Aires region in Argentina. These authors start with the assumption of a linear demand function $Q=a-b P$. In this case, the consumer surplus (the area of a triangle) for new consumers is:

$S=\frac{1}{2}\left(P_{M}-P_{1}\right) Q_{1}$, where $P_{M}$ is the vertical intercept of the demand function, and $P_{1}$ and $Q_{1}$ are price and quantity of new consumers. The inverse demand function is:

$P=\frac{a-Q}{b}=\frac{a}{b}-\frac{1}{b} Q$, and, hence, $P_{M}=\frac{a}{b}$.

Therefore, consumer surplus can also be expressed as:

$S=\frac{1}{2}\left(\frac{a}{b}-\frac{a}{b}-\frac{1}{b} Q_{1}\right) Q_{1}=-\frac{1}{2 b} Q_{1}^{2}$

Remembering that demand elasticity is $\varepsilon=b \frac{P_{1}}{Q_{1}}$ and therefore $b=\varepsilon \frac{Q_{1}}{P_{1}}$,

we obtain the expression for consumer surplus used by Delfino and Casarin (2003, p. 167):

$S=-\frac{1}{2 \varepsilon \frac{Q_{1}}{P_{1}}} Q_{1}^{2}=-\frac{1}{\frac{2 \varepsilon}{P_{1}}} Q_{1}=-\frac{1}{2 \varepsilon} Q_{1} P_{1}=-\left(P_{1} Q_{1}\right) / 2 \varepsilon$,

which can be used to estimate welfare gains for new consumers in scenarios with different elasticities. The results for Buenos Aires show that-gains for new consumers once the cost of 
access (access tariffs and equipment rental) is subtracted are very small or even negative for some services and below some assumptions on elasticities, although infrastructures reached a higher proportion of the population.

In Torero and Pascó-Font (2003), the case of Peru is analyzed. In the first phase, a Probit model of the determinants of the probability of having access to a service is estimated, such as for telephony or electricity:

$$
\operatorname{Pr}(a)=\beta_{1} \ln P_{\text {ins }}+\beta_{2} C O+\beta_{3} I N C \ldots,
$$

where $P_{i n s}$ is the price of installation, CO indicates the degree of access for the zone, and INC is household income. There are sociological variables added, such as race or educational level.

From this equation the inverse Mill ratio is obtained, to correct for the fact that not all the population has access to the service. The inverse Mill ratio adjusts the average error term in the second stage model, given that it does not necessarily have to be 0 , as a consequence of the fact that the second sample includes only "connected" households. This ratio is then included in the estimation in the second stage, that is, in the demand equations, to obtain the price elasticities and the consumer surplus for three services. The equation for each service is then:

$$
\ln \left(Q_{i}\right)=\beta_{0}+\beta_{1} \ln \left(P_{i}\right)+\beta_{2} \ln I N C+\beta_{3} I M R+\ldots
$$

where it is also possible to add sociological variables, and where IMR is the inverse Mill ratio, which depends on the probability of being connected according to the model estimated in the first stage. The results for Peru are that there are clear gains for consumers from the reforms of the telecommunications sector in the 1990s, but not for the energy and water sectors.

More generally, Parker and Kirkpatrick (2005, p. 525) ${ }^{21}$ summarize the existing evidence on the impact of privatizations in developing countries by saying that "the relationship between privatization and performance improvement is complex and superior post-privatization performance is not axiomatic. The evidence reveals that introducing more market competition and effective state regulation may be crucial in ensuring that economic performance improves. In addition, a wider range of institutional issues, including improving political, legal, management and financial capacity within countries will affect the impact of privatization on performance when privatization occurs in low-income countries." 22 The bulk of the evidence on privatization in developing countries is restricted to the telecommunications sector, reflecting the fact that most privatizations have taken place in this sector due to technological changes and growth in demand. The few exceptions in electricity or water illustrate that the success of privatization is indeed possible in terms of higher productivity and improved access

\footnotetext{
21 These authors suggest that some of the existing empirical studies of privatization do not always address satisfactorily a number of methodological problems, such as the choice of counterfactual elements, excessive reliance on accounting data, other data inconsistencies, performance measurement, and causality - good economic performance might lead to privatization rather than vice versa. For a comprehensive survey of empirical studies of privatization not restricted to developing countries, see Megginson (2005).

${ }^{22}$ For evidence along these lines, see Galal et al. (1994), Ros (1999) and Wallsten (2001). López de Silanes and Chong (2003) summarize the empirical evidence on Latin American privatizations, arguing that the manner in which privatization is carried out matters. Transparency and homogeneity of procedures, speed, and limited restructuring prior to privatization lead to better outcomes and less room for corruption and discretion. They also conclude that the success of privatization is enhanced by new regulations and good corporate governance.
} 
and quality conditions, but also highlight the possibility of institutional conflict between government and investors, and the need to accompany privatization by a sound regulatory framework and a feasible competition regime.

What is the link between the impact of regulatory reform on different income groups and political attitudes towards reform? Santhakumar (2006) and Martimort and Straub (2006) provide empirical and theoretical perspectives, respectively, on this issue. Santhakumar (2006) analyzes survey data about attitudes towards reform in the electricity sector in India and reports that those states with more connected households and average quality of service are more prone to oppose reforms such as privatization, because in these states subsidies to electricity consumption are the highest and the gains in terms of newly connected households derived from privatization are minimal. His is, however, a study of initial opposition to reform and not of backlash against existing reforms. Martimort and Straub (2006) build a model motivated by the backlash against privatization in Latin America. They argue that with public ownership the costs are concentrated among dispersed and disorganized tax payers who carry the burden of the soft budget constraint problem. With private ownership the soft budget constraint no longer applies in their model, but well publicized (higher than before privatization) prices concentrated among the connected middle classes can determine a scenario characterized by a strong political opposition compatible with improvements in efficiency.

Harris (2003) analyzes the impact of reforms on the poor, and reports several cases (notably in Chile and Colombia) where private sector involvement has been accompanied by high levels of network expansion in water, sanitation and electricity, as compared with places still under public provision. However, as reported in Easterly and Servén (2003), infrastructure expansion in Latin America in general has been below the expectations raised at the beginning of the 1990s. Harris (2003) also points out that the connected poor, since they spend a higher proportion of their income on utilities services, have suffered disproportionately from tariff increases that have been necessary to attract private investors, and that subsidies to the poor have in several instances not been well enough targeted.

Reform may also have a desirable distributive feature. Engel et al. (2003) argue that concession contracts to private investors (such as Build, Operate, Transfer, or BOT contracts, used for example in toll highway franchising) distribute resources from consumers to taxpayers, if franchises perform under a hard budget constraint (costs have to be covered through tariffs, and not through taxation). If the consumer population is not the total population, as is the case with highways, this may have an equalizing impact on income distribution. ${ }^{23}$ However, Engel et al. (2003) report that many of these franchises in Latin America (they analyze cases from Argentina, Chile and Colombia) were renegotiated and finally did require public funds for cost overruns. They propose that, to avoid such problems in the future, concessions should be accompanied by sectoral regulation separated from ministries to deal with post-contractual hazards, and that franchise periods should be variable to reduce demand risk.

Leipziger et al. (1999) find that public provision does not benefit the poor, but conclude that, with private provision, the public sector must keep a role as regulator and as provider of welltargeted subsidies. They argue that the weaker the regulation, the less protected are the interests of the poor.

\footnotetext{
${ }^{23}$ In addition, average cost pricing has the desirable feature that it is consumer demand, and not public sector planning, that is the key factor in deciding which projects are built at all (this is the traditional Coasian argument in favour of average cost pricing; see Coase, 1946, and Laffont, 2000).
} 


\section{Table 2}

Studies of the Impact of Regulatory Reform on Welfare and Distribution

\begin{tabular}{|c|c|c|}
\hline $\begin{array}{l}\text { Fink, Mattoo and } \\
\text { Rathindran (2002) }\end{array}$ & $\begin{array}{l}\text { Mainline penetration and } \\
\text { efficiency in } \\
\text { telecommunications, LDCs, } \\
1985-1999\end{array}$ & $\begin{array}{l}\text { Comprehensive reform } \\
\text { programs including competition, } \\
\text { privatization and regulatory } \\
\text { independence foster } \\
\text { penetration and efficiency; less } \\
\text { benefits if competition is } \\
\text { introduced after privatization }\end{array}$ \\
\hline $\begin{array}{l}\text { McKenzie and Mookherjee } \\
(2003)\end{array}$ & $\begin{array}{l}\text { Distributive impact of } \\
\text { privatization in Argentina, } \\
\text { Bolivia, Mexico and Nicaragua }\end{array}$ & $\begin{array}{l}\text { Effects of higher prices were } \\
\text { compensated by gain in access, } \\
\text { in welfare terms }\end{array}$ \\
\hline Delfino and Casarin (2003) & $\begin{array}{l}\text { Consumer surplus in Buenos } \\
\text { Aires following the diffusion of } \\
\text { infrastructure }\end{array}$ & $\begin{array}{l}\text { Gains for consumers are small } \\
\text { once cost of access is } \\
\text { considered }\end{array}$ \\
\hline $\begin{array}{l}\text { Torero and Pascó-Font } \\
\text { (2003) }\end{array}$ & $\begin{array}{l}\text { Estimation of consumer welfare } \\
\text { effects of reforms in Peru in the } \\
\text { 1990s }\end{array}$ & $\begin{array}{l}\text { Positive effects for } \\
\text { telecommunications, not for } \\
\text { energy and water }\end{array}$ \\
\hline Santhakumar (2006) & $\begin{array}{l}\text { Attitudes towards reforms in the } \\
\text { electricity sector in India }\end{array}$ & $\begin{array}{l}\text { More opposition to privatization } \\
\text { in states with higher connection } \\
\text { and quality of services }\end{array}$ \\
\hline Harris (2003) & $\begin{array}{l}\text { Impact of privatization on the } \\
\text { poor in Latin America }\end{array}$ & $\begin{array}{l}\text { Benefits from network } \\
\text { expansion, but severe harm } \\
\text { from tariff increases }\end{array}$ \\
\hline $\begin{array}{l}\text { Engel, Fischer, Galetovic } \\
(2003)\end{array}$ & $\begin{array}{l}\text { Effects of concession contracts } \\
\text { to private investors in Latin } \\
\text { America }\end{array}$ & $\begin{array}{l}\text { They tend to transfer from } \\
\text { consumers to taxpayers, but the } \\
\text { latter are usually involved in } \\
\text { covering cost overruns }\end{array}$ \\
\hline $\begin{array}{l}\text { Leipziger, Estache and } \\
\text { Gómez-Lobo (1999) }\end{array}$ & $\begin{array}{l}\text { Impact of privatization on the } \\
\text { poor in Latin America }\end{array}$ & $\begin{array}{l}\text { Public provision does not } \\
\text { benefit the poor, but } \\
\text { privatization should be coupled } \\
\text { with strong regulatory } \\
\text { enforcement to protect the poor }\end{array}$ \\
\hline
\end{tabular}

Table 2 summarizes the main empirical studies reviewed in this section. The direct impact of reforms on consumer welfare (consumer surplus changes) is not the only one that matters, since populations will also be affected by the indirect macroeconomic effects of reforms. Furthermore, the ways direct and indirect effects of policies impact on political attitudes, as well as the vehicles by which those attitudes are translated into political behavior and finally into policy decisions, depend on the role of institutions. Consequently, the analysis of the relationship between regulatory reform, development and inequality would be incomplete without looking at the macroeconomic effects (Sub-section 3.2) and without looking at regulatory institutions (Section 4). 


\subsection{The Impact of Regulatory Reform on Macroeconomic Performance}

We now turn towards the relationship between markets and microeconomic policies, on the one hand, and macroeconomic outcomes on the other hand. The link between micro policies and macro performance, such as productivity, growth, inflation or financial stabilization, is in general a complex field lacking a critical mass of research, despite its clear relevance. Macroeconomic variables condition the decisions about microeconomic policies and therefore we would like to know how aspects such as competition or liberalization affect macroeconomic issues. In developing countries many privatization projects were carried out under the pressure of increasing fiscal deficit and in many cases utilities reform was justified as part and parcel of an economic policy agenda aimed at reinvigorating economic growth. ${ }^{24}$

Although targeting some macroeconomic objectives with microeconomic instruments (initially devised with the "simple" objective of improving efficiency in particular markets) may often not be ideal or efficient, it may be part of a political equilibrium. Therefore, it is useful to explore the costs and benefits of targeting macroeconomic goals with microeconomic instruments (in this case, regulatory reform). This is precisely what is done in Easterly and Servén (2003).

The reduction in investment and public expenditure in infrastructure as part of the economic adjustment of Latin American countries in the 1980s and 1990s is equivalent, according to these authors, to replacing debt with 9\% interest with debt with 20\% interest or even more. Instead of new debt, what took place in most Latin American countries was a cut in public sector expenditure on maintenance and construction of infrastructure. Such expenditures are estimated to have a high social rate of return (they give specific examples ranging from 19\% to $117 \%$ ). ${ }^{25}$ Cutting expenditure on a project that has a high rate of return is economically equivalent to acquiring debt with a high interest rate: both policies free resources today, in exchange for fewer resources tomorrow.

Easterly and Servén are of the view that in the 1980s it had indeed become necessary to improve the health of public finances and that the state economic leadership model was exhausted. What these authors believe to be questionable is the extent to which public expenditure on infrastructure should carry the burden of the cut in fiscal deficit. Latin American countries, although with important internal variations, conform to the pattern that is also described in other studies, according to which infrastructure expenditure in LDCs often suffers a disproportionate compression in times of fiscal austerity. Such compression is largely due to the myopic use of the ratio between the current budget deficit and the GNP as a measure of fiscal performance, while the only fiscal constraint that matters economically is the intertemporal fiscal constraint. Similar criteria of fiscal illusion were used by the EU countries on the occasion of the fulfillment of the Maastricht criteria for the creation of the single

\footnotetext{
24 Other examples of the link between micro and macro, in this case affecting more developed countries, are the "packages" of liberalizing policies to lower inflation, or in general the attempts (through price controls or other interventions) by regional or national governments, who do not have (perhaps because they have voluntarily transferred it, as in the Euro zone) currency sovereignty and hence lack monetary policy instruments, to fight inflation differentials. Similarly, many governments in developed countries are under political pressure to "do something" to fight the outsourcing of local firms or plants of foreign multi-nationals that in the past had established themselves on national soil.

${ }^{25}$ The impact of infrastructure investment on growth can be high if the investment is carried out both by the public or the private sector. See for example, in the transport sector, Banister and Berechman (2000).
}

14 - IESE Business School-University of Navarra 
currency in the 1990s, which coincided with a significant increase in privatizations in countries such as Spain and Italy.

Private provision of infrastructure is seen by these authors as a promising formula, but with few exceptions (which can be found especially in the telecommunications sector) this is a process that finds itself at a very preliminary stage. Even where private provision is feasible, the transition from state to private ownership must be thought through very carefully. Opening up infrastructures to the private sector may make a great deal of sense, but cutting expenditure in infrastructures with a high rate of return and waiting for the private sector to take over overnight is called by Easterly and Servén a "leap of faith." After an exhaustive empirical study, the authors conclude that opening up infrastructure industries to the participation of the private sector has offered mixed results and has not resolved the infrastructure problems in Latin America.

Among the empirical results that these authors present, they find that public infrastructure expenditure has a superior impact on growth when it strongly complements private capital. Moreover, they point out that there is no reason to expect that opening up infrastructure investment to the private sector will attract sufficient investment to compensate public cuts, for two reasons:

- Private investment requires an appropriate institutional and regulatory framework.

- Complementarity and substitutability characteristics between public and private capital may differ across industries.

In fact there is scarce evidence that the decreasing trend in public infrastructure investment has been accompanied by a symmetrically increasing involvement of the private sector in the provision of infrastructures. In some cases, higher private investment was accompanied by higher public investment, suggesting that the public and private sectors often play complementary roles. The authors stress that the only sector where the positive expected reaction from the private sector did emerge was the telecommunications industry.

The substantial impact of infrastructures on growth documented by Easterly and Servén (2003) suggests that the fiscal adjustment of the 1980s and 1990s represented a highly inefficient way to adjust public finances.

Campos et al. (2003) quantify the macroeconomic effects of private sector participation in infrastructure for 21 Latin American countries between 1985 and 1998, although they recognize the data shortcomings of their exercise and the lack of a theoretical model on which they can base their hypotheses. They find that transport reform (airports, ports, railways, roads) has had a significant effect on per capita income, but that utility reform (electricity, gas, sanitation, water, and telecommunications) has no significant effect.

The expenditure, price and tax implications of infrastructure industry reforms extend to all activities, and therefore a general equilibrium approach would be the most appropriate method of evaluation. However, data availability and lack of communication between sub-disciplines of economics has limited the production of such studies. One exception is Benitez et al. (2003) for the case of the reforms in Argentina. Although these authors point out that the reform of utilities in Argentina had a positive effect on national welfare and on distribution, the gains 
from reform were insufficient to offset the losses from the credit shocks ${ }^{26}$ that the Argentinean economy experienced in the 1990s. They rely on a general equilibrium model of the Argentinean economy calibrated for 1993, isolating the distributional effects of utility reform from the impact of other reforms taking place in the country during the 1990s. All agents gain from increases in productivity and access, but the welfare gains are offset by financial crises.

To summarize this section, the empirical results on the impact of reform policies on the welfare of different income groups of consumers are inconclusive. Improved access rates in some areas (although in a context of insufficient infrastructure expansion) are probably compensated by higher and more transparent charges for some groups. The cuts in public infrastructure investment, which accompanied policies to involve the private sector, have done more harm than good to the overall macroeconomic impact of reform policies in highly unequal societies.

\section{Institutions}

\subsection{Why Do Institutions Matter in Infrastructure Industries?}

Institutions matter in any field of economic policy. For example, the econometric treatment of the effects of good institutions ${ }^{27}$ on macroeconomic performance is a very active field of research, and is increasingly inspiring empirical research in microeconomic policies. Dixit (2005) reviews and criticizes this literature. He finds little usefulness in terms of policy prescriptions, and regards with skepticism the tendency to derive recipes from "pure" economic analysis, which should always be complemented by in-depth knowledge of country specificities. In Dixit (2004, p.153) he claims that "institution design or reform is often posed as a matter of binary choices - shock therapy versus gradualism, mimicking western laws versus keeping national or local customs. But this is too simplistic. The best choices typically will be more subtle mixtures of speeds and features that work well in combination; the theory is starting to reveal the desirable complementarities." Credible commitments are seen as one of the few recommendations that survive after many studies, although the recommendation leaves "broad space to fill in the details." Furthermore, he criticizes the role of international institutions, but agrees with those that see them as "facilitators" which allow countries to keep the "ownership" of reforms, while providing them with some discipline. On the other hand, Henisz et al. (2004) state that reforms should not be perceived by local populations as imposed by some distant foreign institution, and that foreign investors gain from associating themselves with local operators who know the communities better and are better known by the stakeholders.

Inequality has been shown (for example in Easterly, 2005; Easterly et al., 2005; and Chong and Gradstein, 2005) to be positively associated with underdevelopment through its effect on hindering the build up of high quality institutions due to political polarization in highly unequal countries, among other channels. A recent report by the Inter-American Development

\footnotetext{
${ }^{26}$ For the relationship between regulatory commitment and macroeconomic shocks, including exchange rate risks, see Harris (2003).

${ }^{27}$ Attention has focused on two types of institutions, those protecting property rights and those enabling private contracts among individuals. See Acemoglu (2004).
} 
Bank stresses the importance of politics in sustaining reforming policies in developing countries. ${ }^{28}$

In infrastructure industries, the importance of institutions ${ }^{29}$ is mainly driven by the sunk nature of the massive investments needed, which is the source of a time inconsistency problem (see the beginning of Section 2 and Subsection 4.2), highlighted by Levy and Spiller (1996), Shirley et al. (2000), Noll (2000), Noll and Shirley (2002) and Newbery (2000), among others. There is no question that many countries have considerable unsatisfied demand and that they face major difficulties in inducing sufficient investment to meet their capacity needs - at least at an acceptable cost of capital. Hence, the role of the regulatory institutions is crucial in providing the credibility that will support the necessary investment flows. Specific regulatory institutions would not be necessary if contracts between consumers (represented through voting in the democratic political process) and investors were self-enforceable, and long term interaction between agents could sustain cooperation. A high discount factor (agents adopting a long term view) is one of the factors yielding cooperation. Self-enforcing mechanisms are studied by Spiller and Tommasi (2005), Newbery (2000) and Levine et al. (2005) among others. The latter show that self-enforced cooperation is actually harder to achieve in regulation than in other fields such as monetary policy, because slow depreciation and slow demand growth increase the length of "temptation periods," which are those periods in which investments provide services without being remunerated, and therefore policy-makers may succumb to the temptation to renege on previous agreements.

When cooperation through punishment threats or reputation cannot be sustained, either rules or specific institutions are necessary to avoid under-investment or hold up as results. Rules have the problem that they may not be robust to unforeseen contingencies. Spiller and Tommasi (2003 and 2005) show that a condition for rigid rules to arise in equilibrium is that the divergence in politicians' interests concerning the issue at hand should be more extreme than the volatility of the underlying economic and technological shocks. Utility regulation, particularly in the early years, seems to be more characterized by distributional aspects than by the importance of adaptation to technological shocks, hence the appeal of a solution based on rules. But, in practice, rule-based solutions seem to lose effectiveness after some time.

The primacy granted to institutional or governance problems in the economic analysis of regulatory reform contrasts, according to Spiller, to the primacy given to capture in the Chicago School tradition or the primacy given to market power in the Toulouse Incentives School. The institutional determinants of private investment in infrastructure have been studied more closely precisely by those authors who followed the path traced by the influential contribution of Levy and Spiller (1996), which has recently been expanded by Spiller and Tommasi (2003 and 2005). These authors propose a conceptual framework for the study of regulation which distinguishes between regulatory governance and regulatory incentives. The former comprises those mechanisms which limit government discretion and solve conflicts between firms and regulators; the latter is related to norms involving price regimes, subsidies, interconnection rates and entry policies. As mentioned above, the main issues related to governance stem from the temptation for governments to renege on commitments previously made with firms which incurred sunk costs to invest in infrastructure. Especially for LDCs, the credibility of

\footnotetext{
${ }^{28}$ See IADB (2006).

${ }^{29}$ Holburn and Spiller (2002) stress that what matters for the success of reforms is the institutional framework, more than industry structure, different industry structures being compatible with success or failure.
} 
commitments not to carry out expropriation activities, ${ }^{30}$ (which may foster electoral support via potential short term benefits for consumers, such as lower prices), is crucial for the ability to secure often badly needed investment in infrastructure. Such credibility is linked to the institutional endowment of a country. Generic laws, in combination with strong presidential systems, for instance, create problems of a lack of credibility in many Latin American countries; Chile is a virtuous exception, as detailed legislation sufficed to attract investment even in the absence of regulatory independence.

Along these lines, Henisz (2000) and Henisz and Zelner (2001) show how a "political constraints" index, measuring the extent of checks and balances which limit wide fluctuations in policy orientation, is strongly associated with network penetration in telecommunications and overall growth rates. The index is mainly based on a combination of veto power in independent branches and the breadth of the ideological spectrum; the results of the data analysis in a large set of countries in the 1960-1994 period are interpreted by Henisz and Zelner (2001) as evidence of the importance of credible protection for investors.

Work on generic microeconomic policies has stressed the complexities of commitment problems. Bardhan (2005) points out that commitment problems may appear not only between policy makers and the private sector, but also between the public (the blockers) and the policy makers, when the public fails to reward potentially efficient policies with re-election, due to fears of a change in the political equilibrium that makes the blockers appear among the political losers. Commitment problems may have a "positive" side (not rewarding welfare enhancing activities, such as investment) or a "negative" side (baling out failing projects). Bardhan (2005) stresses the potential tensions between procedural and participatory democracy and the tendency in democratic unequal societies for the relatively poor majority to undermine the property rights of the rich.

\subsection{The Independence Debate}

One potential way to alleviate the time inconsistency problem in infrastructure policy, which has been explored recently both in developing and in developed countries, is regulatory independence. ${ }^{31}$ If contracts (private contracts or concession contracts) are possible, discretional regulation is less necessary. However, complete contracts are even more problematic in developing countries than in developed ones. Discretional regulation can be replaced by ex ante rules, ${ }^{32}$ but these tend to perform poorly if there are unforeseen contingencies (and it was already mentioned above that it is more difficult to write complete contracts in developing countries than in developed ones). Besides, in many cases regulation and contracts are

\footnotetext{
${ }^{30}$ This is the "overarching" problem in utilities regulation according to Spiller and Tommasi (2005). Only when this problem is fixed or at least alleviated, can optimal contracts, such as those prescribed by the incentives literature (see Laffont and Tirole, 1993), be implemented.

${ }^{31}$ Following Gómez-Ibáñez (2003), spreading the ownership interests widely among the public (another mechanism to alleviate hold up problems that has sometimes been suggested) is not a panacea, because widespread stock ownership is problematic in underdeveloped capital markets with poor legal systems.

32 In monetary policy, as Dixit (2003) warns, it is difficult to sustain central bank independence if this is not accompanied by reputational or other self-enforcing mechanisms. Gómez-Ibáñez (2003) argues that it is hard to regulate well, and one should only regulate when it is essential and with the simplest and least intrusive scheme possible. It is this lesson that lies behind this author's basic preference for private contracts over concession contracts and concessions over discretionary regulation, but incomplete contracts and widespread renegotiation (see Guasch, 2004) make the solution difficult for developing countries.
}

18 - IESE Business School-University of Navarra 
complementary, because i) some sort of supervision is necessary to enforce previous agreements and react to unforeseen contingencies or contract renegotiations; and ii) discretional, independent regulation needs to be accompanied by mechanisms of social control, accountability, and adequate procedures, if it is to obtain social legitimacy and market credibility.

The following picture of an extensive form game summarizes, with the simplest of models, the time inconsistency problem in regulation that gives rise to the "independence" solution:

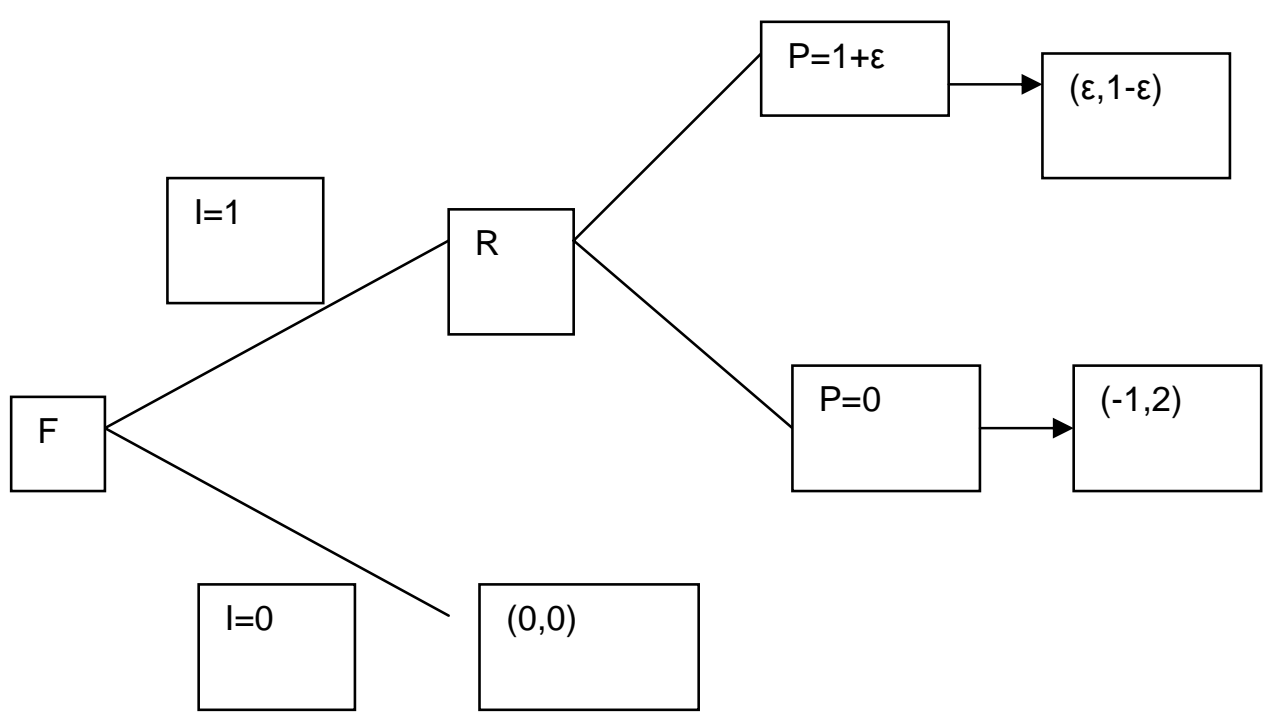

In the game described in the picture, first a firm makes a decision on whether to undertake a specific investment (for example, a hydroelectric generation plant) or not, and next the regulator, if the firm has invested, decides whether to fix a price that remunerates the investment, or to expropriate this investment (zero price). The payoff of the firm is P-I, whereas the payoff of the (consumer welfare maximizing) regulator is 2I-P. By backwards induction, if the firm has invested $(I=1)$, the regulator will rationally fix $P=0$, and, anticipating this, the firm will not invest $(\mathrm{I}=0)$. Hence, in a sub-game perfect equilibrium, there is no investment. More realistic settings would include many other real world details, but if there is no commitment and assets are sunk. Under-investment would remain a serious concern, perhaps in the form of poor maintenance or the use of inefficient technologies. The expropriation of the quasi-rents derived from specific investments ${ }^{33}$ may not necessarily take the form of overly low prices, but it can take other forms, such as unexpected investment requirements, costly unanticipated quality improvements, or requirements to hire inefficient staff. Policy makers may follow this path and still benefit from the (already existing) investments. Ex ante, however, investors will anticipate this, and investment levels will be sub-optimal. The opportunity cost of reneging will depend on country characteristics, such as the institutional endowment, the degree of

\footnotetext{
${ }^{33}$ The relationship between sunk investments and income distribution is nicely described by Newbery (2000, p. 387): "The networks of these utilities are classic natural monopolies that create rents that will be fought over."
} 
inequality, or the nature of the fiscal systems. ${ }^{34}$ In countries with skewed income distributions, governments pay a political price in terms of not satisfying the median (relatively poor) voter if they do not renege on promises made to remunerate specific investments. The problem may be alleviated by long term contracts, repeated interactions, reputational mechanisms or institutions that make credible that the $\mathrm{P}=0$ path will not be taken. Historically, public ownership (the state internalizing the firm's problem) has been a way to alleviate time inconsistency, but in recent decades policy makers in many countries have reached the conclusion that the costs of public ownership in terms of public funds and inefficient practices outweighed its benefits. Hence the solution of privatizing and strategically delegating to a relatively pro-industry regulator, in a similar way to how governments delegate to an inflation-averse central banker (see Levine et al., 2005). ${ }^{35}$ In terms of the encompassing model presented at the beginning of Section 2, now the government delegates in Period 1 to a relatively pro-industry regulator, who has discretion to choose a price in Period 2 to maximize $S(P)+\alpha \Theta(p)$ with $\alpha>1$. Then investment can reach first-best levels again if the government is able to commit to the new institutional arrangement (note that the commitment problem is not solved, but re-located). The need to appoint authorities with a high expertise in complex matters and to avoid policy polarization ${ }^{36}$ reinforces the arguments in favor of delegation.

Spiller and Tommasi (2005) present an interpretation of Spiller and Urbiztondo (1994), a paper on the dilemmas of political appointees versus professional civil servants, in terms of regulatory independence, claiming that the probability of observing independent agencies is higher in systems characterized by divided government. Spiller's argument is that the use of political appointees $^{37}$ ("including independent agencies") arises from the fact that in systems characterized by divided government, the executive has less control over the professional bureaucracy, as the latter will naturally tend to be aligned with the legislature, a political institution that tends to be longer lasting than the executive. Spiller and Tommasi (2005, p.531) claim that in a system with division of powers, "legislative specificity will most probably not be the norm, as legislative costs will be high and preference homogeneity among the members of the legislature will most probably be low, increasing the costs of reversing agencies and courts. It is under these circumstances where we can expect agency independence." The positive correlation between independence and divided governments remains to be tested across countries, to our knowledge.

An issue related to specialized regulators is their possible proximity to the industry and its interests. It is not unusual that in new regulatory agencies a fair proportion of the staff and officials come from the historically incumbent firm. However, that is precisely one of the objectives of strategic delegation: to take into account the rents of the industry. But an independent regulator must not value industry rents excessively, because that would yield overly high prices, possibly getting close to monopoly prices, which is socially costly. This menas that there is a socially optimal level of weight $\alpha$ that the regulator must attach to industry rents, just as there is a socially optimal level of "conservatism" in the independent

\footnotetext{
${ }^{34}$ According to Holburn and Spiller (2002), in environments where fiscal accountability has not been implemented, long term cooperation will be hard to achieve, as deviations will have a high short term payoff.

${ }^{35}$ For a review of the extensive literature on central bank independence, see Berger et al. (2001).

${ }^{36}$ See Faure-Grimaud and Martimort (2005).

${ }^{37}$ An interesting empirical issue would be whether, and to what degree, appointments in regulatory agencies are i) sinecures for career politicans, ii) driven by strategic delegation, or iii) guided by expertise concerns, and whether the difference has any effect on industry outcomes.
} 
central banker. Of course, there are important differences between monetary policy and regulation as far as optimal delegation is concerned:

1) There is more historical experience (and hence higher awareness of the potential problems) of monetary policy than with regulatory policy. ${ }^{38}$ For example, memories of hyper-inflation in Germany, or in some Latin American countries, makes it easier to convince these countries and their authorities of the need to create institutions that are isolated from political short run concerns, to better focus on the solution of the inflation problem. In contrast, regulation of private investment in infrastructures was not the prevalent option in most countries, due to the prevalence of state ownership, until recently.

2) The fact that in infrastructure industries there may be competition (at least in some segments) does not have an exact analogue in central banking. As a result, regulators have to make more decisions, and face interest groups with divergent interests and with a direct stake in policy.

3) The role of asset depreciation and pace of demand growth makes the delegation solution in regulation more appealing than in central banking, but at the same time it makes it more difficult to sustain. That is because slow depreciation or slow demand growth extends the usefulness of current assets and thus increases the temptation to renege on past promises. ${ }^{39}$

4) There is a striking difference in the nature of the task that central bankers and regulators are required to perform. While the central banker has to undertake one main task (fix the interest rate) at regular time intervals, the regulator must undertake multiple tasks (access and final price reviews, merger reports, cases of abuse of dominant position, etc.) at usually irregular time intervals. Therefore, the control that the public or the political "principals" can exert over regulators is much more limited, which is a source of political difficulties and lack of democratic legitimacy, as well as market credibility. More reluctance should be expected to granting regulator independence than to granting central bank independence, ceteris paribus. That is why it is important that independence is accompanied by limited and accountable discretion in a disciplined framework.

The problem of course is that independence does not solve, but relocates, the commitment problem, and transforms itself into one of the government credibly committing not to undermine the independence of the regulator, which many countries have found very difficult. ${ }^{40}$ In this context, the recommendations made by Guasch and Spiller (1999, p.55) about the criteria to take into account when appointing regulators are of interest, although they have to take into account the institutional endowment of each country:

- Prescribe professional qualifications for the personnel appointed.

- Involve both the executive sector and the legislative sector in the appointment.

\footnotetext{
${ }^{38}$ More and more, scholars (see Beato and Laffont, 2002, and Gómez-Ibáñez 2003, for example) report interesting accounts of private investment in infrastructures in the 19th or early 20th centuries, but probably these experiences do not influence contemporary public perception.

${ }^{39}$ See Levine et al. (2005).

${ }^{40}$ See Gual and Trillas (2004 and 2006).
} 
- Establish a high cost of removing the regulator from her position, but contemplate the possibility of removal in case of proven poor behavior.

- Prescribe specific duties and obligations in as clear a way as possible and arbitrate an appeals process, involving the judicial power or another forum.

- Impose high standards of transparency in the regulatory process.

However, insulating agencies from politics may have the undesired effect of maintaining policies that are not politically feasible in the medium to long run. Some political discretion that allows for well targeted concessions to stakeholders may be useful for making short term agreements, gaining the collaboration of some agents and increasing the political legitimacy of policies. Reform policies need local politicians who can build alliances that make policies feasible on the ground. Henisz et al. (2005) emphasize that policy reforms that have not been perceived as imposed from abroad, and that involve local investors, have higher political legitimacy than those that are seen as "foreign" solutions.

A few countries have been effective in attracting private investment without an independent regulator, most notably Chile. Engel et al. (2003) mention that the protection of property rights in Chile must be traced back to the economic reforms in the mid-seventies. The unpleasant coincidence of these reforms with a brutal military dictatorship puts a question mark over the possibility of replicating the Chilean experience in other jurisdictions. ${ }^{41}$ Engel and his coauthors, moreover, claim that some of the problems in Chilean privatization may be alleviated with independent regulators separate from the ministries in charge of planning for infrastructure expansion. Spiller and Tommasi (2005) also claim that in countries such as the UK, with unified governments (centralized structures where the executive controls the legislative) the existence of independent agencies (whose statutes may be easily changed by a law) is not the main factor driving private investment, but it is the contract licenses that provide the assurance that investments will not be expropriated. The incomplete nature of such contracts, however, is conveniently supplemented by the works of regulatory agencies with qualified staff.

On the empirical front, ${ }^{42}$ the focus of cross-national econometric studies has been on the role of independent regulators in stimulating private investment (for telecoms, typically proxied by the total number of mainlines or mainlines per 100 inhabitants), primarily in developing countries. In general, data used for telecoms are better, as there is more experience with telecom regulation than with other utilities (although telecom regulator independence is still a very recent phenomenon in most countries).

None of the econometric studies undertaken have data on regulatory processes or practice; the only regulatory data that exists is mainly in relation to the legal framework, which describes, for example, whether there is a regulatory law, whether the regulator is formally independent, how it is funded, etc. A major task for future research is to include evidence on regulatory processes and practices and how they evolve over time, (for example, the percentage of regulatory agency commissioners, or office heads, whose tenure is ended prematurely). The absence of data on regulatory processes and practices is unfortunate given that the evidence

\footnotetext{
${ }^{41}$ Dixit (2005) also mentions more generally the unpleasant logic behind the possibility that some dictatorships may be more credible in protecting the property rights of the rich.

42 This review of the empirical studies on regulatory independence draws from Levine et al. (2005).
} 
suggests that, in developing countries, the quality of the law typically exceeds the quality of its application and enforcement, so that the quality of the legal framework exaggerates the quality of regulation in practice. It means that coefficient estimates on the regulatory variable are likely to be downward biased because of an errors-in-variables problem.

These problems must be added to the one of finding a common desirability of outcomes across a large set of countries. In spite of these difficulties, Wallsten (2001) finds that installing a regulatory agency separate from the relevant ministry before privatization is positively and significantly associated with several indicators of investment. Wallsten's regulatory variable was a simple time-dated dummy of whether or not a regulator had been enacted in law. The same is true of the regulatory variable in the study of 86 non-OECD countries by Fink et al. (2002) on telecommunications. This study finds that the existence of an independent regulatory agency significantly augments the (positive) effect on mainline penetration of competition and privatization. Furthermore, Fink et al. stress the importance of sequencing in reform policies in telecommunications, ${ }^{43}$ after analyzing LDC data in the $1985-1999$ period. Their main result is that mainline penetration and efficiency enjoy substantial increases on average after comprehensive programs including privatization, the introduction of competition and the setting up of an independent regulatory entity; these beneficial effects are severely reduced if competition is introduced after privatization.

Estache et al. (2006) assess the effects of private capital and independent regulatory agencies on telecommunications performance by using cross-country panel data from 1990 to 2003. In general, they find that having independent regulatory agencies positively affects affordability and labor productivity, but negatively affects quality.

Gutierrez (2003) and Gual and Trillas (2004 and 2006) are the first studies to associate indices to regulatory institutions, in the spirit of the literature on central bank independence. Gutierrez (2003) estimates the effect of a seven-item index of regulatory governance on mainline density and efficiency for 22 Latin American and Caribbean countries. He finds that both the index and the three main subcomponents have a positive and significant effect (at the $1 \%$ level) on mainline penetration, after controlling for competition and privatization. This holds for both static and dynamic models and the estimated coefficients are robust to corrections for potential endogeneity.

Gual and Trillas (2004) present and use an index of regulatory independence in telecommunications for 37 countries, constructed using principal components techniques and thus taking into account the correlation between the original variables. They find that legal independence is more likely in countries with a larger incumbent and in countries with worse rule of law measures. They take this as evidence the fact that incumbent firms lobby for independent agencies and that independence is a substitute for other ways to commit not to expropriate the incumbent's quasi-rents. They find that independence has a positive but not significant impact on network penetration, using International Telecommunications Union data.

Cubbin and Stern (2004) use a four-component index of regulatory independence to estimate the effect of regulation on investment in electricity generation in a sample of 28 developing countries for the period 1980-2001. They estimate fixed effects panel data models similar to those of Gutierrez (2003). They find that the impact of a maximum index score (i.e. a regulator

\footnotetext{
${ }^{43}$ See also Li and Xu (2002 and 2004) for related studies.
} 
established by primary legislation, autonomous, funded from license fees or similar and with freedom in setting pay) is, on average, likely to increase expected long-run per capita generation capacity levels by around $15-25 \%$. This is the predicted increase relative to an otherwise average developing country having electricity regulation conducted by a ministry without any supporting law.

However, as one might expect, the estimated regulatory effects take some time to build up. The estimated long-run impact of a regulator established for less than 12 months on per capita generation capacity was zero whereas for a regulator (autonomous and/or ministry) established for at least three years, it was in the 25-35\% range. Similarly, a simple quadratic formulation suggested that the long-run impact continued to increase for over ten years. Finally, lags appear to be long. Hence, the results from an error correction model showed that only about $12 \%$ of the expected long-run regulation effects on generation capacity levels could be expected to occur in the first year. All of these results provide support for the expectation that considerable time is needed (a) to build up regulatory capacity; and (b) for the regulatory agency to establish its reputation vis-à-vis investors.

Wallsten (2002) focuses on the sequence of regulatory reforms concerning independence of the regulator and privatization. When privatization processes enjoyed wide political support, arguments were often raised in favor of speeding up such processes. However, his analysis, which makes use of data from 200 countries from 1985 to 1999 on performance in telecommunication industries, stresses the importance of establishing an independent regulatory authority before the beginning of the privatization process, with high benefits in investment, fixed telephone penetration, and cellular penetration.

The empirical literature on testing whether (and, if so, how and why) utility regulatory agencies help alleviate the time inconsistency problems associated with private investment is, however, still in its infancy with respect to, for instance, the independent central bank literature. Nevertheless, the relevant empirical literature is increasingly providing strong evidence that a positive degree of regulatory independence may have a positive impact in some contexts.

\subsection{Regulatory Governance}

There are other aspects of regulatory governance ${ }^{44}$ that go beyond independence and, although important, have been less emphasized by the academic literature: ${ }^{45}$

i) An important decision is whether regulatory agencies should be collective bodies or single person organs. The main advantages of the single person regulator are swift decision making, clear accountability, administrative cost minimization, predictable outcomes, and absence of partisan allocation of positions. The main advantages of collegiate agencies are resistance to individual agendas, resistance to capture, multiple perspectives, and the possibility of staggering terms to lessen links with the incumbent government. The optimal decision (see Guasch and Spiller, 1999) will depend on the tasks that the regulator must undertake, the context of the country or industry and the global institutional framework. Guasch and Spiller (1999) conclude that resistance to capture should prevail, and that this tilts the balance for

\footnotetext{
${ }^{44}$ For an overview of related issues, see Brown et al. (2006).

${ }^{45}$ However, for a previous review of similar issues, see Estache and Martimort (1999).
} 
developing countries in favor of collegiate bodies, but even that must be calibrated in a local context.

ii) Another important decision is whether to create multi-utility agencies. The trend in some developed countries such as the UK or Spain is to create agencies that oversee related industries (OFCOM and OFGEM in the UK, CNE in Spain), which facilitates transparency and reputation and reduces instability and regulatory risk. In developing countries, the scarcity of qualified personnel and the existence of capture risks reinforce the validity of this option (taken for example by Bolivia), but the drawback is that multi-utility agencies also reinforce the multi-task problem of controlling regulators and make their social control more difficult (see Laffont, 2005; Beato and Laffont, 2002).

iii) Finally, there is the issue of whether regulation should be performed at national level or in a decentralized way. Institutional endowment here is crucial, as is technology. For example, electricity regulation in Argentina takes place at the provincial level (like in Canada and Australia, where it takes place at the state level), whereas in many other countries it is centralized. Not many studies have undertaken an in-depth analysis of the optimal allocation of regulatory powers, either from a theoretical or from an empirical point of view. The issue is mentioned by Aubert and Laffont (2002), Laffont (2005) and Gómez-Ibáñez (2003), ${ }^{46}$ but there is clearly a scarcity of academic work in this field, if compared, for example, with its sister discipline of fiscal federalism. ${ }^{47}$ What are the determinants of the allocation of regulatory decisions in the vertical chain of government? Both from a positive and normative perspective, the potential determinants that have been mentioned in the literature, besides technology and regulatory endowment, are:

- Jurisdictional spillovers, which, for example, would make electricity transmission (where the physical rules do not have much respect for political boundaries) a central or supra-national policy, but distribution and supply a regional, decentralized issue.

- Capture potential. It is not clear whether capture can be higher at the central or at the local level. It depends on features of the political systems and on the details of the supply and demand for lobbying. ${ }^{48}$ The relative potential for capture across levels of government varies with space and time.

- Asymmetric information. This gives an advantage to decentralized regulation, but yardstick competition mechanisms would require some level of central information or at least of coordination of dispersed information.

- Commitment capacity at the different government levels, which depends on the quality of institutions and the rule of law.

- Capacity to recruit specialized personnel. This is particularly relevant in those industries that experience technological change and in those countries where

\footnotetext{
${ }^{46}$ See also Brennan (2003) and Smith (2000).

${ }^{47}$ See for example Oates (1999).

${ }^{48}$ See Bardhan and Mookherjee (2000).
} 
highly trained personnel are particularly scarce, which tilts the balance in favor of central agencies.

In the literature on fiscal federalism, the Oates theorem ${ }^{49}$ states that if policy makers are benevolent and there are no jurisdictional spillovers, the lower government level dominates the higher one because it better reflects citizens' preferences and provides superior information. Like many important theorems in economics, this one provides a benchmark, and must be interpreted as an invitation to investigate, in each particular case, if any of the theorem's assumptions do not hold. Of course, in many countries the timing of reforms does not allow for a first-best fine tuning of the right policy location (as it often does not allow for the perfect fine tuning of firms' boundaries or of firms' governance), but the analysis of "regulatory federalism" may help in identifying those features of governance that must be reformed to make a given policy location work in the best long-term interest of consumers. An overall preference for central regulation (as for example reflected in Gómez-Ibáñez, 2003), or for decentralized regulation (as reflected in Qian and Weingast, 1997; and Weingast, 2003, and their theory of market-preserving federalism), seems unjustified. And sometimes some role for both levels simultaneously in one policy area may be necessary, as for some forms of supralocal support, as argued for example in Bardhan (2005, p.124).

\subsection{Capture}

As we have just seen, the risk of capture conditions any of the previous decisions on regulatory governance. But capture encompasses a wide range of different phenomena, not necessarily with the same implications. For example, while it is widely accepted that public ownership invites some forms of corruption (patronage, soft budget constraints), private ownership makes possible other forms of collusion between private sector agents and policy makers (regulatory capture, favoritism at auctions, collusion between politicians and managers at the expense of voters and shareholders). The same or very similar models of regulatory capture can be used to address different phenomena such as direct bribing of policymakers, the "revolving doors" phenomenon, and presenting biased or partial information to regulators. It is clear that these forms of lobbying have very different implications in terms of political legitimacy or even legality.

A form of costly capture may be to appoint managers with a political or bureaucratic background (see Joskow et al., 1993 and 1996). More generally Straub (2005) speaks of "payroll corruption." A hypothetical example of this would be if just prior to full privatization of, say, an electricity firm, the government appointed as chairman of the firm a typical archetype of machine politics who learned his skills in the corridors of power, although he had no background whatsoever in the electricity industry or even in the management of any firm. After the firm is fully privatized (although the government may keep a golden share for several years) the investors decide to keep this chairman because they rationally think that he may be able to achieve political advantages in a politicized regulatory arena (after all, he will be familiar with the corridors of power). Levy and Spiller (1996) argue that infrastructure sectors are inherently politicized, given the fact that all voters are consumers, that regulated firms are very large, and the sunk nature of their investments.

\footnotetext{
${ }^{49}$ Oates (1999).
} 
It seems clear that in many developing countries, and most notably in Latin America, some degree of capture ${ }^{50}$ has been necessary to attract foreign capital in the utilities sector. Levine et al. (2006) provide a first theoretical attempt to show that an optimal degree of firms' influence on regulators may alleviate both the underinvestment problem and the ratchet effect problem (under-provision of effort), in the absence of regulatory commitment. Evans et al. (2006) compare such a "capture solution" to the "independence solution" to the commitment problem. In terms of the encompassing model presented at the beginning of Section 2 above, now the firm, besides having the possibility of incurring investment expenditures in Period 1 to achieve lower fixed costs in Period 2, has the possibility, also in Period 1, of spending resources on lobbying contributions, $L$, so that the firm and the regulator reach an agreement that a certain regulated price will prevail in Period 2. The intertemporal profits of the firm are now:

$$
\Theta(P)=-i-L+\delta[(p-c) D(p)-k+f(i)]
$$

And the regulator chooses the price to maximize $S(p)+\beta(L) \Theta(p), \beta^{\prime}(L)>0$, so that the weight of profits in the regulator's objective function positively depends on lobbying expenditures.

This may also yield first-best investment levels, although the solution is more costly than delegating to an independent regulator because the lobbying expenditures must be covered by prices.

There are obvious limitations to this strategy in terms of political legitimacy. In the recent past, as mentioned in the introduction, there has been a backlash against privatization and foreign investment (most dramatically in Bolivia, but in general in all Latin American countries to different degrees, see Kessides 2004). There is a heavy cost in terms of some sort of capture (and therefore rent) that must be allowed to attract private investment and effort. It is then not surprising that in countries with very weak welfare states, and a very high cost of public funds, poor citizens focus on these rents to demand redistributive policies.

Ugaz and Waddams-Price (2003, p.11) argue that incentives can only work if those responsible for making efficiencies keep a significant part of the rewards. If the results of the effort are all immediately redistributed (for example to other workers or consumers) then they are unlikely to be realized in the first place. There is a clear trade-off between providing incentives for efficiency and increased investment and how quickly those benefits are shared with other parties involved in the process. However, the same authors admit that "The World Bank itself has increasingly focused its attention on the effects on the poor of reform packages which it supports. (...) Despite recognition of some trade-off between efficiency, incentives and redistribution, some shift in emphasis is evident." This follows, according to the authors, a situation where regulation has been weak in the face of firms. They argue that Spanish firms have been strong enough (between themselves, with interlocking directorates, and between them and the banks) to capture Spanish and Latin American regulators. For the case of Chile, the authors mention that "a related problem, affecting both the capacity of active participation of consumers in the process and the supply of competent regulatory services, is the lack of a

\footnotetext{
50 Engel et al. (2003) point out that the Chilean Ministry of Public Works granted public refinancing on franchised concessions even after the roads where built and sunk. They find two (not necessarily alternative) explanations for this. First, bailing out current operators gives an incentive to them to participate in future franchise auctions (this argument would work if public workers were farsighted). And second, companies captured public workers (some officials of the ministry had to resign due to corruption allegations).
} 
sufficiently large pool of trained regulators. Those available quickly become engaged working for the companies, either directly (with much higher financial rewards than the government offers) or representing them on regulatory boards. This leaves few independent professionals whose opinions can influence the debate, help consumers to articulate demands, and make regulation more transparent and participatory."

On the theoretical front, Laffont (2000), after reviewing the more traditional literature of the Chicago school, presents a model where the risk of capture makes it socially optimal to reduce regulatory discretion so that the stakes of regulation are low (the impact of regulation on profits is diminished). The effects of regulatory stakes on lobbying are long lasting. Costly lobbying decisions by firms usually have a long term nature. As mentioned above, regulated utilities often hire managers with a bureaucratic background or with political connections. This sacrifices intertemporal profits if the firm pays a cost in terms of efficiency and/or if the manager is compensated by an incentive mechanism related to profits. Similarly, a regulated firm may hire a lobbying firm through a long term contract; it makes sense that such a contract is long term because the lobbying firm must develop relationships with regulators, politicians, and the media. Then this contract may also be related to performance in terms of the firm's profits.

We are not the first to claim that a limited degree of capture may be a feature conducing to higher investment in a less than perfect world (i.e., in the absence of commitment). Armstrong and Vickers (1996, p.303) argue that "as to the question of industry-specific regulatory bodies versus ones with wider scope, we do not see decisive arguments either way. The danger of capture might argue against industry-specific bodies, but a degree of capture might enhance the credibility of commitment to allow an adequate return on investment." They make this claim in the context of the analysis of the right policies in the regulation and liberalization of former communist countries to alleviate under-investment in sunk assets, which the authors view as the main problem transition countries face in the reform of telecommunications.

Along similar lines, two papers (to our knowledge) argue that the "revolving doors" phenomenon should be allowed to some extent: first Che (1995), who makes this claim on the basis of the prospect of future employment in the industry, among other effects, which increases the efforts of the regulator, with some spillover effects on his activity in pursuing public interest; secondly, Salant (1995) maintains that staggered terms between managers and regulators lead the latter to think twice before reneging on sunk investments, if they have some chance of becoming managers in the future.

Other papers emphasize the positive informational effects of some degree of capture, such as Grossman and Helpman (2001), who show how lobbies provide information on the productive environment that is useful although biased, or provide information on the behavior of regulators that is useful to political principals.

Table 3 compacts the empirical studies reviewed in this section and in Sub-Section 3.2. To summarize this section, institutions determine how the time inconsistency problem in the presence of sunk investments is addressed. An independent regulator is theoretically a sound proposition, but it is more difficult to sustain than central bank independence. Other regulatory governance issues matter as much, and also determine to a great extent the particular ways in which the commitment problem is addressed. When other more desirable and legitimate ways of achieving commitment are absent, some degree of capture is left as an option to alleviate underinvestment (but at the risk of triggering a political backlash).

\section{Table 3}


Empirical Studies About Macroeconomics and Institutions of Regulatory Reform

\begin{tabular}{|c|c|c|}
\hline Easterly and Servén (2003) & $\begin{array}{l}\text { Effects of cuts in public expenditure } \\
\text { in infrastructure in Latin America }\end{array}$ & $\begin{array}{l}\text { The quest for expenditure reduction } \\
\text { results in an inefficient strategy in } \\
\text { the long term, as public and private } \\
\text { investment are often } \\
\text { complementary. Privatization } \\
\text { brought about significant benefits } \\
\text { only in telecommunications. }\end{array}$ \\
\hline $\begin{array}{l}\text { Campos, Estache, Martín and } \\
\text { Trujillo (2003) }\end{array}$ & $\begin{array}{l}\text { Macroeconomic effects of } \\
\text { privatization, Latin America, 1985- } \\
1998\end{array}$ & $\begin{array}{l}\text { Benefits from reforms in } \\
\text { transportation (airport, railway, } \\
\text { ports, roads) on income, no } \\
\text { significant effects from reforms in } \\
\text { utilities }\end{array}$ \\
\hline $\begin{array}{l}\text { Benitez, Chisari and Estache } \\
\text { (2003) }\end{array}$ & $\begin{array}{l}\text { Effect of reforms in utilities in } \\
\text { Argentina in the 1990s }\end{array}$ & $\begin{array}{l}\text { Positive welfare effects were } \\
\text { insufficient to compensate for } \\
\text { negative effects of credit shocks }\end{array}$ \\
\hline Henisz and Zelner (2001) & $\begin{array}{l}\text { Impact of checks and balances } \\
\text { summarized in a political } \\
\text { constraints index, large set of } \\
\text { countries, 1960-1994 }\end{array}$ & $\begin{array}{l}\text { Political constraints foster network } \\
\text { penetration in telecommunications } \\
\text { and overall growth, as they } \\
\text { strengthen the credibility of investor } \\
\text { protection. }\end{array}$ \\
\hline Wallsten (2002) & $\begin{array}{l}\text { Effects of sequencing of regulatory } \\
\text { reforms in telecommunications, } 200 \\
\text { countries, 1985-1999 }\end{array}$ & $\begin{array}{l}\text { The set-up of an independent } \\
\text { regulator before privatization is key } \\
\text { in achieving beneficial effects on } \\
\text { penetration and efficiency }\end{array}$ \\
\hline $\begin{array}{l}\text { Estache, Goicoechea and } \\
\text { Manacorda (2006) }\end{array}$ & $\begin{array}{l}\text { Effects of privatization and } \\
\text { independence, cross-country panel, } \\
\text { 1990-2003 }\end{array}$ & $\begin{array}{l}\text { Independence of the regulator in } \\
\text { privatization reforms positively } \\
\text { affect affordability and labor } \\
\text { productivity, but has negative } \\
\text { effects on quality }\end{array}$ \\
\hline Gutierrez (2003) & $\begin{array}{l}\text { Effect of sound regulatory } \\
\text { governance index, } 22 \text { Latin } \\
\text { American countries, 1980-1997 }\end{array}$ & $\begin{array}{l}\text { Positive effect on mainline } \\
\text { penetration, even after controlling } \\
\text { for privatization and competition } \\
\text { (which in turn also have positive } \\
\text { effects) }\end{array}$ \\
\hline Gual and Trillas (2006) & $\begin{array}{l}\text { Impact of regulatory independence } \\
\text { as defined in a new index, } 37 \\
\text { countries }\end{array}$ & $\begin{array}{l}\text { Independence is correlated with } \\
\text { strong incumbents and weak rule of } \\
\text { law, and is used as a means to } \\
\text { provide credibility not to expropriate } \\
\text { investors' rents }\end{array}$ \\
\hline Cubbin and Stern (2004) & $\begin{array}{l}\text { Independence index, } 28 \text { countries, } \\
\text { 1980-2001: effects in the electricity } \\
\text { sector }\end{array}$ & $\begin{array}{l}\text { High independence increases long- } \\
\text { run capacity generation by } 25 \%\end{array}$ \\
\hline
\end{tabular}

\section{Conclusions}

In this paper, we survey studies that analyze how the specific features of developing countries condition reforms in infrastructure industries. We also summarize research that examines the effects of reforms on income groups and on macroeconomic performance, and assess how 
regulatory institutions provide a link between distributive issues and actual policies. The conclusions that we can extract from our review of the literature are the following:

1) Expectations about private sector involvement in infrastructures were probably too high in the early 1990s, and have already been lowered, partly for good reasons. Private sector provision has inherent political difficulties, both because the firms' rents necessary to attract investment become more visible, and because prices are also more visible than widely dispersed and highly opaque fiscal deficits (usual under public ownership and provision). Still, a reversion to the old paradigm of public provision and ownership is not happening and should not necessarily happen. If private sector involvement is accompanied by a well functioning regulatory framework, efficiency gains are likely, and these can be distributed in a way that leads to politically sustainable reforms.

2) In regulatory reform, efficiency and distribution are hardly separable. High income inequality exacerbates the dilemmas between rents and incentives inherent in the design of optimal regulation, and may seriously undermine the political feasibility of regulatory reforms. A high cost of using the tax system, coupled with enormous social needs and high inequality, imply high pressure to redistribute any rents known to be generated. In particular, there is a high short term opportunity cost of not reneging on the commitment not to expropriate the quasi-rents necessary to remunerate sunk investments in infrastructure sectors.

3) Competition and privatization are feasible ${ }^{51}$ in developing countries, and have the potential to increase efficiency and at the same time benefit the poorest segments of the population. The empirical evidence is not conclusive as to the real effects of existing reforms on income inequality. The most that can be said is that regulatory reform did not improve the acute inequalities of some regions, such as Latin America (although there are exceptions, most notably Chile). Perception and transparent firms' rents greatly complicated the politics of reforms. The main obstacles are not to be found in technological or economic aspects, but within the realm of politics and institutions. This does not mean that economists have already done their job, but they have to contribute to understanding and at least propose how to alleviate the political and institutional hazards. As López de Silanes and Chong (2003, p. 44) argue, "the understanding of the political economy mechanisms behind the causes of failure should be used to improve privatization, not to stop it."

4) In the quest for effective universal service policies, distributional concerns become particularly critical. Universal service programs should create special funds (from all operators that achieve a given market share, or from general taxation if the tax system is sufficiently- developed), using the vertical chain of government to carefully target subsidies. Direct subsidies are preferable to cross subsidies because they do not

\footnotetext{
${ }^{51}$ An illuminating success story (which also illustrates the potentially constructive role that economists can play) is the case of transport in Chile's capital, Santiago. In 2005, a new bus system that replaced the inefficient previous one was in place after a competitive concession bidding process; new inner city toll highways allowed commuters and visitors to go in and out of the capital in less than half an hour; and new underground parking spaces had been in operation for two or three years in several central areas. Foreign investors participated in all these concessions. Chilean economists had been very active in the debate and public policy process that preceded these changes. See Díaz et al. (2004) and Engel et al. (2003). Some commentators argued that these spectacular changes boosted the chances of the official candidate in the two-round presidential election of December 2005/January 2006. Postcontracting problems, however, were not absent: some operators of the new bus system complained that "pirate" buses were operating in some of the concessioned routes (see newspaper El Mercurio, December 23, 2005).
} 
jeopardize liberalization, but they must run in parallel with fiscal policy reforms and with an improvement in the quality of government (otherwise we would be back to the previous stage, where company deficits were financed through opaque fiscal deficits). Better governments and better markets are complements.

5) Institutions matter, and in regulation this is often associated with the option of granting independence to some agencies to take decisions within clearly defined frameworks. But other dimensions of governance must also be taken into account: accountability, procedures, decentralization, coordination, legitimacy. Importing institutional quality through links with international agencies or regulators from other countries may be useful, as long as it is not perceived as an imposition on local democracies.

6) Regulatory reform should be part of an overall strategy to increase growth and develop sound institutions.52 Some characteristics of developing countries (e.g. tax systems and existing levels of corruption) should not be just taken as given, and should be addressed at the same time or prior to regulatory reform.

7) Reforms directed at increasing private investment had better results in the telecommunications sector than in other sectors. Among other possible determinants of this difference, increasing demand growth, higher scope for competition, and faster asset depreciation may account for part of the differential. These features make the credibility of commitments not to expropriate sunk investments more sustainable.

Future research looks promising in the following areas:

- Establishing rigorously, through a well-structured empirically ${ }^{53}$ testable theoretical model, the link between inequality, politics, reform and investment that has been informally formulated throughout this survey.

- Combining theoretical and empirical work to better establish the link between formal independence and practical mechanisms to achieve institutional commitment compatible with limited discretion.

- Considering more in depth the key instruments to increase access by the poor. Although some lessons across sectors are useful, these instruments should in general be sector specific. For example, broadband expansion and policies to fight the digital divide ${ }^{54}$ should be carefully analyzed, to find the best combination towards important goals such as lowering entry barriers and fostering new product development, on the one hand, and developing a sound public sector policy to subsidize access, on the other. ${ }^{55}$

\footnotetext{
52 Far-sighted firms should thus lobby for policies that enhance growth opportunities and the development of welfare states, because such policies would sustain political majorities in favour of reforms. Baron (1996) stresses the importance of firms' non-market strategies.

${ }^{53}$ A key data source for empirical work in this field is Wallsten et al. (2004).

54 Soria (2002) points out that Internet development will be even more related to human development than technology adoption is.

${ }^{55}$ See Wallsten (2005). This paper provides a quantification of the existence and importance of the digital divide.
} 


\section{References}

Acemoglu, D., S. Johnson (2004), “Unbundling Institutions," Journal of Political Economy, 113(5): 949-995.

Armstrong, M., Vickers, J. (1996), "Regulatory Reform in Telecommunications in Central and Eastern Europe," Economics of Transition, 4(2): 295-318.

Armstrong, M., Sappington, D. (2003), "Recent Developments in the Theory of Regulation," forthcoming in Handbook of Industrial Organization, vol. III.

Aubert, C., Laffont, J.-J. (2002), “Designing Infrastructure Regulation in Developing Countries,” in Beato and Laffont, eds., 2002, Competition Policy in Regulated Industries. Approaches for Emerging Economies, Washington DC: Inter-American Development Bank.

Banerjee, A. V. (2004), "Inequality and Investment, mimeo.”

Banister, D., Berechman, J. (2000), Transport Investment and Economic Development, London: UCL Press.

Bardhan, P. (2005), Scarcity, Conflicts, and Cooperation. Essays in the Political and Institutional Economics of Development, Cambridge: The MIT Press.

Bardhan, P., Mookherjee, D. (2000), "Capture and Governance at Local and National Levels," American Economic Review, 90(2): 135-139.

Baron, D. (1996), Business and Its Environment, Second Edition, Upper Saddle River: Prentice Hall.

Basanes, F., Willig, R., eds. (2001), Second-Generation Reforms in Infrastructure Services, Washington DC: IADB and The John Hopkins University Press.

Beato, P. (2002), "Cross-Subsidy Prices in Public Utilities," in Beato and Laffont, eds., 2002, Competition Policy in Regulated Industries. Approaches for Emerging Economies, Washington DC: Inter-American Development Bank.

Beato, P., Laffont, J.-J. eds. (2002), Competition Policy in Regulated Industries. Approaches for Emerging Economies, Inter-American Development Bank.

Benítez, D., Chisari, 0., Estache, A. (2003), "Can the Gains from Argentina's Utilities Reform Offset Credit Shocks?" in Ugaz and Waddams-Price, eds., Utility Privatization and Regulation. A Fair Deal for Consumers? Cheltenham: Edward Elgar.

Berger, H., de Haan, J., Eijffinger, S.C.W. (2001), "Central Bank Independence: An Update of Theory and Evidence," Journal of Economic Surveys, 15(1): 3-40.

Bertola, G. (2000), "Macroeconomics of Income Distribution and Growth," in A.B. Atkinson and F. Bourguignon (eds.), Handbook of Income Distribution, vol. I, Amsterdam: North Holland.

Bertola, G., Foellmi, R., Zweimuller, J. (2006), Income Distribution in Macroeconomic Models, Princeton: Princeton University Press.

Besanko, D., Spulber, D.F. (1993), "Contested Mergers and Equilibrium Antitrust Policy," Journal of Law, Economics, and Organization, 9: 1-29. 
Brennan, T. J. (2003), "State and Federal Roles in Facilitating Electricity Competition: Legal and Economic Perspectives,” Resources for the Future, Discussion Paper 03-24.

Brown, A.C., Stern, J., Tenenbaum, B. (2006), Handbook for Evaluating Infrastructure Regulatory Systems, Washington DC: The World Bank.

Campos, J., Estache, A., Martín, N., Trujillo, L. (2003), "Macroeconomic Effects of Private Sector Participation in Infrastructure," in Easterly and Servén, The Limits of Stabilization. Infrastructure, Public Deficits and Growth in Latin America. Washington DC: Stanford University Press and The World Bank.

Che, Y.-K. (1995), "Revolving Doors and the Optimal Tolerance for Agency Collusion," RAND Journal of Economics, 26(3): 378-397.

Chisari, 0., Estache, A., Waddams-Price, C. (2003), “Access by the Poor in Latin America's Utility Reform: Subsidies and Service Obligations," in Ugaz and Waddams-Price, eds., Utility Privatization and Regulation. A Fair Deal for Consumers? Cheltenham: Edward Elgar.

Chong, A., Gradstein, M. (2004), "Inequality and Institutions," Inter-American Development Bank Working Paper \#506.

Coase, R. (1960), “The Problem of Social Cost,” Journal of Law and Economics, 3: 1-44.

Coase, R. (1946), “The Marginal Cost Controversy,” Economica, 13: 169-82.

Cook, P., Kirkpatrick, C., Minogue, M., Parker, D. , eds. (2004), Leading Issues in Competition, Regulation and Development, Edward Elgar.

Cubbin, J., Stern, J. (2004), "Regulatory Effectiveness: The Impact of Good Regulatory Governance on Electricity Industry Capacity and Efficiency in Developing Countries," Regulation Initiative WPS, 57, London Business School.

Delfino, J., Casarin, A. (2003), "The Reform of the Utilities Sector in Argentina," in Ugaz and Waddams-Price, eds., Utility Privatization and Regulation. A Fair Deal for Consumers? Cheltenham: Edward Elgar.

Díaz, G., Gómez-Lobo, A., Velasco, A. (2004), "Micros en Santiago: de enemigo público a servicio público," Estudios Públicos, 96: 5-48.

Dixit, A. (2003), "Some Lessons from Transaction-Cost Politics for Less-Developed Countries," Economics and Politics, 15(2): 107-133.

Dixit, A. (2004), Lawlessness and Economics. Alternatives Modes of Governance, Princeton: Princeton University Press.

Dixit, A. (2005), “Evaluating Recipes for Development Success,” World Bank DEC Lectures.

Easterly, W. (2005), “Inequality Does Cause Underdevelopment,” mimeo.

Easterly, W., Servén, L. (2003), The Limits of Stabilization. Infrastructure, Public Deficits and Growth in Latin America. Washington DC: Stanford University Press and The World Bank.

Easterly, W., Ritzen, J., Woolcock, M. (2005), “Social Cohesion, Institutions, and Growth,” mimeo. 
Elster, J. (1992), Local Justice. How Institutions Allocate Scarce Goods and Necessary Burdens, Cambridge: Cambridge University Press.

Engel, E., Fischer, R., Galetovic, A. (2003), "Privatizing Highways in Latin America: Fixing What Went Wrong," Economia: Journal of the Latin American and Caribbean Economic Association, 4(1): 129-158.

Estache, A., Martimort, D. (1999), "Politics, Transaction Costs, and the Design of Regulatory Institutions,” World Bank Policy Research Working Paper, 2073.

Estache, A., Foster, V., Wodon, Q. (2002), Accounting for Poverty in Infrastructure Reform. Learning from Latin America's Experience, Washington DC: World Bank Institute.

Estache, A., Goicoechea, A., Manacorda, M. (2006), "Telecommunications Performance, Reforms and Governance," mimeo.

Estache, A., Perelman, S. and L. Trujillo (2005), "Infrastructure performance and reform in developing and transition economies: evidence from a survey of productivity measures," World Bank Policy Research Working Paper 3514.

Evans, J., Levine, P., Trillas, F. (2006), "Lobbies, Delegation and the Under-Investment Problem in Regulation," forthcoming in International Journal of Industrial Organization.

Faure-Grimaud, A., Martimort, D. (2005), "Political Stabilization by an Independent Regulator," mimeo.

de Ferranti, D., Perry, G., Ferreira, F. H.G., Walton, M., (2003), Inequality in Latin America and the Caribbean. Breaking with History? Washington DC: The World Bank.

Fink, C., Mattoo, A. and R. Rathindran (2002), "An Assessment of Telecommunications Reform in Developing Countries," World Bank Policy Research Working Paper 2909.

Galal, A., Jones, L., Tandon, P., Vogelsang, I. (1994), Welfare Consequences of Selling Public Enterprises: An Empirical Analysis, Oxford: Oxford University Press.

Gómez-Ibáñez, J. A. (2003), Regulating Infrastructure. Monopoly, Contracts and Discretion, Cambridge: Harvard University Press.

Grossman, S., Helpman, E. (2001), Special Interest Politics, Cambridge: The MIT Press.

Gual, J., Trillas, F. (2004), “Telecommunications Policies: Determinants and Impact,” CEPR Discussion Paper 4578.

Gual, J., Trillas, F. (2006), “Telecommunications Policies: Measurement and Determinants," Review of Network Economics, 5(2): 249-272.

Guasch, J. L. (2004), Granting and Renegotiating Infrastructure Concessions. Doing It Right, WBI Development Studies, Washington DC: The World Bank.

Guasch, J.L., Spiller, P. (1999), Regulatory Reform in Latin America and the Caribbean, Washington DC: World Bank.

Guasch, J.L., Laffont, J.J. and S. Straub (2002), "Renegotiations of concession contracts in Latin America," World Bank Policy Research Working Paper 3011. 
Gutiérrez, L. (2003), "The Effect of Endogenous Regulation on Telecommunications Expansion and Efficiency in Latin America," Journal of Regulatory Economics, 23(3): 257-268.

Harris, C. (2003), "Private Participation in Infrastructure in Developing Countries," World Bank Working Paper \#5.

Hausman, J. (1998), "Valuing the Effects of Regulation on New Services in Telecommunications," Brookings Papers: Microeconomics, 1-38.

Henisz, W.H. (2000), "The institutional environment for economic growth," Economics and Politics, 12(1): 1-31

Henisz, W.H., Zelner, B.A. (2001), "The institutional environment for telecommunications investment," Journal of Economics \& Management Strategy, 10(1): 123-147.

Henisz, W., Zelner, B., Guillén, M. (2004), "International Coercion, Emulation and Policy Diffusion: Market Oriented Infrastructure Reforms, 1977-99,” William Davidson Institute Working Paper Number 713.

Holburn, G.L.F., Spiller, Pablo T. (2002), "Institutional or Structural: Lessons from International Electricity Sector Reforms," in Brosseau, Eric, and Jean-Michel Glachant, eds., The Economics of Contracts. Theories and Applications, Cambridge: Cambridge University Press.

IADB (2006), The Politics of Policies: Economic and Social Policies in Latin America, Washington DC: Inter-American Development Bank and David Rockefeller Centre for Latin American Studies, Harvard University.

Jamasb, T. (2006), "Between the State and Market: Electricity Sector Reform in Developing Countries," Utilities Policy, 14: 14-30.

Joskow, P.L., Rose, N.L., Shepard, A. (1993), "Regulatory Constraints on CEO Compensation," Brookings Papers: Microeconomics, 1-72.

Joskow, P.L., Rose, N.L., Wolfram, C.D. (1996), "Political constraints on executive compensation: evidence from the electric utility industry," Rand Journal of Economics, 27 (1): 165-182.

Kessides, I.N. (2004), Reforming Infrastructure. Privatization, Regulation and Competition. Washington DC: World Bank and Oxford University Press.

Krueger, A., ed. (2000), Economic Policy Reform: The Second Stage, Chicago: University of Chicago.

Laffont, J.-J. (2000), Incentives and Political Economy, Oxford: Oxford University Press.

Laffont, J.-J. (2005), Regulation and Development, Cambridge: Cambridge University Press.

Laffont, J.-J., Tirole, J. (1993), A Theory of Incentives in Procurement and Regulation, Cambridge: The MIT Press.

Leipziger, Z., Estache, A., Gómez-Lobo, A. (1999), "Utility Privatization and the Needs of the Poor in Latin America. Have We Learned Enough To Get It Right?” World Bank Working Paper \#2407.

Levine, P., Rickman, N., Trillas, F. (2006), "Price Regulation and the Commitment Problem: Can Capture Be Beneficial?” mimeo. 
Levine, P., Stern, J., Trillas, F. (2005), "Utility Price Regulation and Time Inconsistency. Comparisons with Monetary Policy,” Oxford Economic Papers 57: 447-478.

Levy, B., Spiller, P.T. (1996), Regulations, Institutions, and Commitment: Comparative Studies of Telecommunications, Cambridge: Cambridge University Press.

Li, W., Xu, L. (2002), "The Political Economy of Privatization and Competition: Cross-Country Evidence from the Telecommunications Sector," Journal of Comparative Economics, 30(3): 439462.

Li, W., Xu, L. (2004), "The Impact of Privatization and Competition in the Telecommunications Sector around the World," Journal of Law and Economics, 47(3): 395-430.

Loeb, M. and Magat, W.A. (1979), “A Decentralized Method of Utility Regulation,” Journal of Law and Economics 22: 399-404.

López de Silanes, F., Chong, A. (2003), “The Truth about Privatization in Latin America," Yale ICF Working Paper, 03-29.

McKenzie, D., Mookherjee, D. (2003), "The Distributive Impact of Privatization in Latin America: Evidence from Four Countries," Economia: Journal of the Latin American and Caribbean Economic Association, 3(2): 161-218.

Martimort, D., Straub, S. (2006), “Privatization and Corruption,” mimeo.

Megginson, W. L. (2005), The Financial Economics of Privatization, Oxford: Oxford University Press.

Milgrom, P., Roberts, J. (1990), "Bargaining Costs, Influence Costs, and the Organization of Economic Activity," in Alt, J.E., Shepsle, K.A., eds., Perspectives on Positive Economy, Cambridge: Cambridge University Press.

Motta, M. (2004), Competition Policy. Theory and Practice, Cambridge: Cambridge University Press.

Neven, D.J., Röller, L.-H. (2005), “Consumer Surplus versus Welfare Standard in a Political Economy Model of Merger Control," International Journal of Industrial Organization, 23(9-10): 829-848.

Newbery, D. (2000), Privatization, Restructuring and Regulation of Network Utilities, Cambridge: The MIT Press.

Noll, R. (2000), "Telecommunications Reform in Developing Countries," in Anne Krueger, ed., Economic Policy Reform: The Second Stage, Chicago: University of Chicago.

Noll, R., Shirley, M. (2002), “Telecommunications Reform in Sub-Saharan Africa: Politics, Institutions and Performance," mimeo.

Oates, W. E. (1999) “An Essay on Fiscal Federalism," Journal of Economic Literature, Vol. XXXVII: 1120-1149.

Parker, D., Kirkpatrick, C. (2005), "Privatisation in Developing Countries: A Review of the Evidence and the Policy Lessons," Journal of Development Studies, 41(4): 513-541.

Qian, Y., Weingast, B. R. (1997), "Federalism as a Commitment to Preserving Market Incentives," Journal of Economic Perspectives, 11(4): 83-92. 
Rey, P., Gual, J., Hellwig, M., Perrot, A., Polo, M., Schmidt, K., Stenbacka, R. (2005), “An Economic Approach to Article 82," Brussels: Report by the Economic Advisory Group on Competition Policy.

Ros, A. (1999), "Does Ownership or Competition Matter? The Effects of Telecommunications Reform on Network Expansion and Efficiency," Journal of Regulatory Economics, 15: 65-92.

Salant, D. J. (1995), "Behind the Revolving Door: A New View of Public Utility Regulation," RAND Journal of Economics, 26(3): 362-377.

Santhakumar, S. (2005), Impact of the Distribution of the Cost of Reform on Social Support for Reforms. A Study of Power Sector Reforms in Indian States, Gurgaon: India Development Foundation.

Shirley, M., Cowan, S., Noll, R. (2000), "Reforming Urban Water Systems in Developing Countries," in Anne Krueger, ed., Economic Policy Reform: The Second Stage, Chicago: University of Chicago.

Smith, W. (2000), "Regulating Utilities: Thinking about Location Questions," paper presented at the World Bank's World Development Report 2002 Summer Research Workshop, 17-19 July, Washington, D.C.

Soria, B. (2002), “The Importance of Social Factors in the Penetration of Wireline Services," mimeo.

Soria, B. (2005), "The Unsuitability of European and US Regulatory Frameworks for Latin American Countries," mimeo.

Spiller, P.T., Cardilli, C.G. (1997), "The Frontier of Telecommunications Deregulation: Small Countries Leading the Pack," Journal of Economic Perspectives, 11(4): 127-138.

Spiller, P.T., Tommasi, M. (2003), "The Institutional Foundations of Public Policy: A Transactions Approach with Application to Argentina," Journal of Law, Economics and Organization, 19(2): 281-306.

Spiller, P.T., Tommasi, M. (2005), “The Institutions of Regulation. An Application to Public Utilities,” in Handbook of New Institutional Economics, Dordrecht: Springer.

Spiller, P.T., Urbiztondo, S. (1994), "Political Appointees vs. Career Civil Servants: A MultiplePrincipals Theory of Political Institutions," European Journal of Political Economy, 10: 465497.

Straub, S. (2005), “Opportunism, Corruption and the Multinational Firm’s Mode of Entry,” mimeo.

Torero, M., Pascó-Font, A. (2003), "The Social Impact of Privatization and the Regulation of Utilities in Peru," in Ugaz and Waddams-Price, eds., Utility Privatization and Regulation. A Fair Deal for Consumers? Cheltenham: Edward Elgar.

Ugaz, C., Waddams-Price, C. (2003), Utility Privatization and Regulation. A Fair Deal for Consumers? Cheltenham: Edward Elgar.

Wallsten, S.J. (2001), "An Econometric Analysis of Telecom Competition, Privatization and Regulation in Africa and Latin America," Journal of Industrial Economics, 49(1): 1-19.

Wallsten, S.J. (2002), "Does Sequencing Matter? Regulation and Privatization in Telecommunications Reforms,” World Bank Policy Research Working Paper 2817. 
Wallsten, S.J. (2005), "Regulation and Internet Use in Developing Countries," Economic Development and Cultural Change, 53(2): 501-523.

Wallsten, S.J., Clarke, G., Haggarty, L., Kaneshiro, R., Noll, R., Shirley, M., Colin Xu, L. (2004), New Tools for Studying Network Industry Reform in Developing Countries: The Telecommunications and Electricity Regulation Database, AEI-Brookings Joint Center for Regulatory Studies Related Publication 04-05, March 2004.

Weingast, B.R. (2003), "The Economic Role of Political Institutions: Market-Preserving Federalism and Economic Development," Constitutional Political Economy, Vol. II.

Zajac, E.E. (1995), Political Economy of Fairness, Cambridge: the MIT Press. 